\title{
Watching Over, Watching Out: Lawyers' Responsibilities for Nonlawyer Assistants
}

\author{
Douglas R. Richmond ${ }^{*}$
}

\section{INTRODUCTION}

Lawyers depend on the efforts and support of many different nonlawyer assistants to practice. Law firms could not operate without nonlawyer staff. Legal secretaries perform numerous tasks essential to lawyers' work. Accounting staff create and send bills, process fee payments, and manage operating and trust accounts. In litigation practices, legal assistants-paralegals, if you prefer-manage various aspects of cases, prepare discovery responses, conduct fact investigations, research expert witnesses, and more. In transactional practices, legal assistants frequently handle Uniform Commercial Code filings and other key submissions, perform various records searches, and coordinate the assembly and collection of closing documents. Law firms with intellectual property practices employ patent agents to perform patent searches, prepare and record patent assignments, and prepare, file, and prosecute patent applications. Summer associates and law clerks perform important legal research, draft documents for review by lawyers, and undertake a variety of other practical responsibilities. Lawyers reach outside their firms for assistance from appraisers, private investigators, process servers, and e-discovery vendors. Large law firms outsource various projects to a range of service providers. The list of nonlawyers who regularly assist lawyers goes on.

Unfortunately but understandably, nonlawyer assistants sometimes err. Although it is lamentable, it is true also that nonlawyer assistants are occasionally guilty of deliberate misconduct. Lawyers who are called to account by clients, courts, or disciplinary authorities for events attributable in whole, or in major part, to their nonlawyer assistants' mistakes or misconduct may be tempted to shift responsibility from

Managing Director, Professional Services Group, Aon Risk Services, Chicago, Illinois. J.D., University of Kansas; M.Ed., University of Nebraska; B.S., Fort Hays State University. Opinions expressed here are the author's alone. 
themselves to their allegedly culpable assistants. In general, lawyers cannot escape professional responsibility in this fashion. ${ }^{1}$ Under common law principles, a court may hold a lawyer responsible for a nonlawyer assistant's conduct in imposing sanctions or when enforcing deadlines. $^{2}$ As an agency law matter, a lawyer may be liable for an assistant's errors committed in the scope of the assistant's employment. ${ }^{3}$ Liability based on the doctrine of respondeat superior is a settled aspect of tort law. Finally, but critically, Model Rule of Professional Conduct 5.3 and equivalent state rules frequently prohibit lawyers from disavowing responsibility for assistants' conduct in the context of professional discipline by imposing broad supervisory responsibilities on lawyers. ${ }^{4}$ Forty-nine states and the District of Columbia have adopted Model Rule 5.3 in whole or part; ${ }^{5}$ California is the exception, although the Golden State is headed toward adoption of the Model Rules. ${ }^{6}$

The reasoning behind Rule 5.3 is straightforward. Clients hire lawyers to represent them and, while they understand that lawyers may delegate aspects of their work to law firm staff, they expect lawyers to appropriately supervise the performance of those services. ${ }^{7}$ More

1. See, e.g., Att'y Grievance Comm'n of Md. v. Ambe, 38 A.3d 390, 408-09 (Md. 2012) (facing discipline under Maryland Rule 7.1 for misleading statements on his letterhead, the lawyer defended on the basis that he instructed his paralegal to obtain new letterhead, but the paralegal failed to do so; the court rejected this argument because the lawyer bore "ultimate responsibility" for complying with ethics rules); In re Gargano, 957 N.E.2d 235, 238-39 (Mass. 2011) (rejecting lawyer's attempt to blame his accountant for mishandling of retainer); In re Montoya, 266 P.3d 11, 23 (N.M. 2011) (criticizing lawyer who attempted to deflect blame for missing deadlines to his staff for "shirking his own responsibilities"); In re Martin, 699 S.E.2d 695, 697-98 (S.C. 2010) (rejecting lawyer's partial defense that his errors were attributable to high staff turnover and to staff's failure to advise him about client's attempts to contact him).

2. See, e.g., Henderson v. Pac. Gas \& Elec. Co., 113 Cal. Rptr. 3d 692, $703-05$ (Cal. Ct. App. 2010) (refusing to allow a lawyer relief from a missed summary judgment deadline where the late filing was principally caused by a paralegal's misjudgments and mistakes, reasoning that the lawyer was responsible for supervising the paralegal's work, and thus became responsible for the paralegal's failure to timely file the subject document).

3. RESTATEMENT (THIRD) OF AGENCY § 2.04 (2006); see, e.g., In re Estate of Divine, 635 N.E.2d 581, 587-88 (Ill. App. Ct. 1994) (recognizing that lawyer could be sued for malpractice based on paralegal's conduct).

4. Model Rules of Prof'L Conduct R. 5.3 (2012).

5. See Alphabetical List of States Adopting Model Rules, ABA, http://www.americanbar.org/groups/professional_responsibility/publications/model_rules_of_profes sional_conduct/alpha_list_state_adopting_model_rules.html (last visited Sept. 19, 2012) (identifying jurisdictions that have adopted the Model Rules, including Rule 5.3, in some form).

6. Renee Choy Ohlendorf, California May Get New Rules of Professional Conduct, LitiG. NEws (Sept. 21, 2011), http://apps.americanbar.org/litigation/litigationnews/top_stories/092111california-ethics-model-rules-of-professional-conduct.html.

7. Ronald D. Rotunda \& John S. DZienKowski, Legal Ethics: THE LAWYeR'S DESKBOOK ON PROFESSIONAL RESPONSIBILITY § 5.3-1, at 1006 (2012-2013). 
broadly, clients expect a law firm's partners or shareholders to establish reasonable standards for the delivery of high-quality representation by everyone in the firm, and by contractors or vendors on whom the firm relies. In addition, efforts at regulating lawyers' professional conduct would be ineffective if lawyers could circumvent ethics rules by instructing or knowingly permitting lay assistants to violate them in their place. ${ }^{8}$ Model Rule 5.3 thus fits hand-in-glove with Model Rule 5.1, which governs lawyers' supervisory responsibilities with respect to fellow lawyers, whether as partners or shareholders with overall responsibility for their law firms, or as direct supervisors of subordinate lawyers. ${ }^{9}$ Together, the two rules establish a comprehensive, flexible supervisory regime.

Although lawyers' supervisory responsibilities for their nonlawyer assistants seem obvious, lawyers all too often fail in them-or perhaps fail to appreciate or recognize them until it is too late. There are numerous reasons for these lapses. Busy lawyers must delegate work to their staff and, absent red flags related to staff members' competence, diligence, or reliability, it is easy to become complacent as a supervisor. Indeed, the reality of practice is not just that lawyers must delegate work to assistants, but that they must also be able to trust their assistants, and need for such trust commonly dulls lawyers' supervisory instincts. Lawyers may overestimate staff members' capabilities and thus fail to appreciate the need to provide guidance or oversight. Geographical factors complicate some supervisory relationships. Lawyers sometimes employ relatives as assistants and incorrectly assume that family ties negate the need for supervision. ${ }^{10}$ In some instances, lawyers have

8. Id.

9. See Model Rules of Prof'L Conduct R. 5.1 (2012) (establishing “Responsibilities of Partners, Managers, and Supervisory Lawyers”). For additional information on lawyers' supervisory duties under Rule 5.1, see Arthur J. Lachman, What You Should Know Can Hurt You: Management and Supervisory Responsibility for the Misconduct of Others Under Model Rules 5.1 and 5.3, PROF. LAW., 2007, 18(1), 1, 1-2 ; Douglas R. Richmond, Law Firm Partners as Their Brothers' Keepers, 96 Ky. L.J. 231, 236-46 (2007-2008); Douglas R. Richmond, Subordinate Lawyers and Insubordinate Duties, 105 W. VA. L. REV. 449, 451-58 (2003).

10. See, e.g., In re Finestrauss, 32 A.3d 978, 979-80 (Del. 2011) (per curiam) (reprimanding lawyer for failing to supervise his bookkeeper-wife, who failed to pay various payroll tax obligations); In re Otlowski, No. 127, 2009, 2009 WL 1796083, at *3, *5 (Del. June 23, 2009) (reprimanding lawyer whose daughter stole from his escrow account); In re Shamers, 873 A.2d 1089, 1094, 1098 (Del. 2005) (suspending lawyer for protracted failure to supervise his bookkeeperwife); In re Galasso, 940 N.Y.S.2d 88, 91-93 (N.Y. App. Div. 2012) (per curiam) (suspending lawyer whose bookkeeper-brother misappropriated client funds), aff'd as modified, _N.E.2d_, 2012 WL 5199400 (N.Y. Oct. 23, 2012) (affirming violation of supervisory responsibilities but remanding for reconsideration of suspension as appropriate sanction after unrelated disciplinary 
employed or retained nonlawyer assistants who were obviously unworthy of the attendant opportunities. ${ }^{11}$ Even more frustrating, from a lawpractice-management perspective, lawyers have employed or retainedwith little or no forethought or supervision-plainly unfit lay assistants whose excuses, perceived abilities, or purported reformation apparently overcame the lawyers' better judgment. ${ }^{12}$

While many of the reported cases arising out of lawyers' alleged supervisory lapses involve lawyers in small firms and solo practitioners, large law firms have also been burned by nonlawyer staff misconduct. ${ }^{13}$ Rule 5.3 does not expressly factor law firm size into lawyers' supervisory duties, although the measures, procedures, or steps required to comply with the Rule necessarily vary with the practice environment. $^{14}$

charge was held to be unfounded); State ex rel. Okla. Bar Ass'n v. Hill, 281 P.3d 1264, 1268, 1272 (Okla. 2012) (finding that lawyer violated Oklahoma Rule 5.3 by failing to supervise his officemanager-wife, who vindictively misappropriated funds from the lawyer's operating and trust accounts); In re McClain, 719 S.E.2d 675, 675-76 (S.C. 2011) (per curiam) (violating South Carolina Rule 5.3 by failing to supervise bookkeeper-wife, who was able to embezzle client funds from trust accounts as a result); In re Vanderbeek, 101 P.3d 88, 93-94 (Wash. 2004) (disciplining lawyer whose bookkeeper-husband habitually inflated clients' bills; lawyer was not initially aware of husband's fraudulent scheme even though minimal review of the bills or billing process should have revealed it).

11. See, e.g., In re Maccione, 710 S.E.2d 745, $746-47$ (Ga. 2011) (per curiam) (finding violations of Georgia Rules 5.3(b) and 8.4(a) but rejecting petition for voluntary discipline that imposed only a reprimand where the lawyer employed an investigator-paralegal who was not licensed as an investigator, who had no paralegal education, and who possessed a long criminal history, and the investigator-paralegal engaged in the unauthorized practice of law and stole from a client); In re Bennett, 32 So. 3d 793, 796-99 (La. 2010) (per curiam) (suspending lawyer for violating Louisiana Rule 5.3 where paralegal stole funds from trust account; the paralegal had been accused of embezzling $\$ 100,000$ from a previous employer but denied those accusations and the lawyer continued to employ her but did not restrict her access to the source of funds from which she stole); N.C. State Bar. v. Leonard, 632 S.E.2d 183, 185-86, 189 (N.C. Ct. App. 2006) (involving lawyer's failure to supervise assistant who was a convicted felon).

12. See, e.g., In re Disciplinary Action Against Houge, 764 N.W.2d 328, 336 (Minn. 2009) (per curiam) (finding that lawyer violated Minnesota Rule 5.3 in failing to supervise a client who had been convicted of bank fraud and theft by swindle who the lawyer hired as an independent contractor to assist in the lawyer's real estate foreclosure practice); Miss. Bar v. Thompson, 5 So. 3d 330, 337-38 (Miss. 2008) (involving a lawyer who hired a convicted armed robber and forger as a paralegal).

13. See, e.g., Ameet Sachdev, Ex-Mayer Brown Exec Allegedly Embezzled, CHI. TRIB., Aug. 31, 2012, Sec. 2, at 3 (reporting that the former chief information officer at a respected global law firm allegedly embezzled over $\$ 850,000$ from the firm during a twelve-month period); Bridget Heos, Ex-legal Secretary Pleads Guilty to Embezzling Client Funds, KC Bus. J. (Nov. 6, 2006), http://www.bizjournals.com/kansascity/stories/2006/10/30/daily50.html?page=all (reporting that a legal secretary at a large Missouri law firm embezzled nearly \$160,000 from client trust accounts over a three-year period).

14. See Restatement (ThiRd) OF the LAW GOVERNing LAWYers § $11 \mathrm{cmt}$ g (2000) (“Appropriate measures for a particular firm must take account of the particular firm's size, 
This Article analyzes lawyers' professional responsibilities regarding their nonlawyer assistants. Part II focuses on the duties imposed on lawyers by Rule 5.3 and state equivalents. Importantly, Part II explains that Rule 5.3 does not impose vicarious liability on lawyers. ${ }^{15}$ Part III discusses Rule 8.4(a), which states that it is unethical for a lawyer to "violate or attempt to violate the Rules of Professional Conduct, knowingly assist or induce another to do so, or do so through the acts of another." 16 Cases in which lawyers are charged with violating Rule 5.3 frequently involve alleged Rule 8.4(a) violations, as well. Part IV discusses the other leading standard governing lawyers' conduct in this context: section 11 of the Restatement (Third) of the Law Governing Lawyers. ${ }^{17}$ Section 11 addresses both professional discipline and lawyers' civil liability. ${ }^{18}$ Part IV also discusses lawyers' potential vicarious liability for their nonlawyer assistants' alleged misconduct under the respondeat superior doctrine, as well as their direct liability for negligent supervision under the common law. Finally, Part V explores four special supervisory concerns for lawyers: (a) the employment of family members, (b) the employment of disbarred lawyers as nonlawyer assistants, (c) the use of private investigators, and (d) the professional responsibility challenges that outsourcing poses when the outsourced work will be done by nonlawyers.

\section{LAWYERS’ SUPERVISORY RESPONSIBILITIES UNDER MODEL RULE \\ 5.3}

Lawyers' many professional responsibilities include broad supervisory obligations. Lawyers' supervisory obligations regarding other lawyers are framed in Rule 5.1. ${ }^{19}$ Lawyers' duties to supervise nonlawyer assistants under Rule 5.3 closely parallel their duties to supervise fellow lawyers under Rule 5.1. ${ }^{20}$ There are, however, two key

structure, nature of practice, and legal constraints, as well as the foreseeability of particular kinds of supervisory issues arising.”).

15. See Model Rules of Prof'L CONDUCt R. 5.3(c) (2012) (explaining lawyers' responsibility for the actions of another person within the firm).

16. Id. R. 8.4(a).

17. Restatement (ThiRd) OF THE LaW Governing Lawyers § 11 (2000) (“A Lawyer’s Duty of Supervision”). 11).

18. See infra notes 194-201 and accompanying text (explaining this construction of section

19. Model Rules of Prof'L Conduct R. 5.1 (2012) (“Responsibilities of Partners, Managers, and Supervisory Lawyers").

20. ROTUNDA \& DZIENKOWSKI, supra note 7, § 5.3-1, at 1005. 
differences between the Rule 5.1 and Rule 5.3 regimes. First, lawyers generally must supervise nonlawyer assistants more closely than they supervise other lawyers because nonlawyer assistants usually lack formal legal education or training; yet, lawyers are responsible for ensuring that nonlawyer assistants perform their professional duties competently, diligently, faithfully, and honestly. ${ }^{21}$ Second, because nonlawyers cannot be held to the same professional standards as lawyers, Rule 5.3 requires that nonlawyer assistants' conduct be "compatible with" supervisory lawyers' professional obligations, rather than matching them exactly, as is required of subordinate lawyers. ${ }^{22}$ Rule 5.3 provides:

With respect to a nonlawyer employed or retained by or associated with a lawyer:

(a) a partner, and a lawyer who individually or together with other lawyers possesses comparable managerial authority in a law firm shall make reasonable efforts to ensure that the firm has in effect measures giving reasonable assurance that the person's conduct is compatible with the professional obligations of the lawyer;

(b) a lawyer having direct supervisory authority over the nonlawyer shall make reasonable efforts to ensure that the person's conduct is compatible with the professional obligations of the lawyer; and

(c) a lawyer shall be responsible for conduct of such a person that would be a violation of the Rules of Professional Conduct if engaged in by a lawyer if:

(1) the lawyer orders or, with the knowledge of the specific conduct, ratifies the conduct involved; or

(2) the lawyer is a partner or has comparable managerial authority in the law firm in which the person is employed, or has direct supervisory authority over the person, and knows of the conduct at a time when its consequences can be avoided or mitigated but fails to take reasonable remedial action. ${ }^{23}$

Rule 5.3 recognizes that lawyers must delegate work to nonlawyer assistants but, at the same time, that such delegation must be

21. Mark L. Tuft, Supervising Offshore Outsourcing of Legal Services in a Global Environment: Re-examining Current Ethical Standards, 43 AKRON L. REV. 825, 831 (2010).

22. 2 Geoffrey C. HaZard, JR. \& W. William Hodes, The LaW of LAWYering § 44.2, at 44-4 (3d ed. 2001 \& Supp. 2010).

23. Model Rules of Prof'L CONDUCt R. 5.3 (2012). 
appropriate. ${ }^{24}$ The key to appropriate delegation is proper "supervision" by the lawyer. ${ }^{25}$ Supervision as contemplated in Rule 5.3 includes training nonlawyer assistants, but the concept is clearly not so limited. ${ }^{26}$ Lawyers must also provide adequate instruction when assigning projects to nonlawyer assistants, monitor the progress of projects they delegate to nonlawyer assistants, review assistants' completed work, and, as necessary, explain the ethical contours of assistants' assignments. ${ }^{27}$ The intensity or level of instruction and supervision required will naturally vary by project or task and assistant. ${ }^{28}$ In any event, lawyers are "completely responsible" for their nonlawyer assistants' performance. ${ }^{29}$ This may be true even where the lawyer is serving in a managerial capacity rather than actually practicing law, although authority is split on this final point. ${ }^{30}$

Lawyers may be held to violate Rules 5.3(a) and (b) even where they are unaware of assistants' misconduct. ${ }^{31}$ Because violations of Rules 5.3(a) and (b) rest on lawyers' supervisory failures, rather than participation in or failure to remedy assistants' misconduct, knowledge of assistants' offenses is not required. ${ }^{32}$ Indeed, it is logical to assume that a lawyer charged with violating Rule 5.3(a) or (b) would not know

24. In re Comish, 889 So. 2d 236, 245 (La. 2004) (per curiam); Disciplinary Counsel v. Ball, 618 N.E.2d 159, 161 (Ohio 1993).

25. In re Comish, 889 So. $2 \mathrm{~d}$ at 245.

26. See, e.g., In re Quinn, 184 P.3d 235, 245 (Kan. 2008) (per curiam) (distinguishing between the lawyer's training of her secretary and her supervision of the secretary's conduct).

27. In re Comish, 889 So. $2 \mathrm{~d}$ at 245.

28. Douglas R. Richmond et Al., Professional ResPonsibility in Litigation 169 (2011).

29. In re Comish, 889 So. 2d at 245; see also In re Montoya, 266 P.3d 11, 23 (N.M. 2011) (per curiam) (describing repeated errors by nonlawyer staff as a failure by the lawyer); State ex rel. Okla. Bar Ass'n v. Hill, 281 P.3d 1264, 1272 (Okla. 2012) (“A lawyer is duty-bound to supervise the work of his hired hands.”); State ex rel. Okla. Bar Ass’n v. Taylor, 4 P.3d 1242, 1251 (Okla. 2000) (stating that a lawyer "stands ultimately responsible for work done by all nonlawyer staff").

30. Compare Att’y Grievance Comm'n of Md. v. Johnson, 976 A.2d 245, 266 (Md. 2009) (applying Maryland Rule 5.3 to lawyer-owner of title company even though lawyer was not then practicing law), with In re Marriage of Redmond \& Bezdek, 131 P.3d 1167, 1171 (Colo. App. 2005) (explaining that Colorado Rule 5.3 applies only to lawyers engaged in law practice and thus did not apply to lawyer serving as minor child's special advocate in a divorce case).

31. See, e.g., In re Hall, 876 So. 2d 47, 48-49 (La. 2004) (per curiam) (finding violation of Louisiana Rule 5.3 by failing to supervise a disbarred lawyer employed as a secretary and paralegal).

32. See, e.g., People v. Calvert, 280 P.3d 1269, 1283 (Colo. 2012) (explaining that lawyer could have learned of paralegal's misconduct through "[b]asic oversight and simple diligence," but even if he had "no inkling" of the paralegal's misconduct, he still would have violated Colorado Rule 5.3(b) by inadequately supervising her work); In re Geiger, 27 So. 3d 280, 285 (La. 2010) (per curiam) (finding that lawyer violated Louisiana Rules 5.3(a) and (b) where bookkeeper misappropriated trust account funds without the lawyer's knowledge). 
of an assistant's misconduct until after the fact precisely because of the lawyer's supervisory lapses. ${ }^{33}$ Lawyers may violate these rules through conduct that is merely negligent. ${ }^{34}$

The application of Rule 5.3 in practice raises several key issues, including (a) the identification of nonlawyers under the Rule; (b) the range of relationships encompassed by the Rule; (c) the contours of the Rule 5.3(a) requirement that partners and other lawyers with managerial authority make reasonable efforts to assure that nonlawyer assistants behave ethically; (d) the relationship or responsibility required for lawyers to have "direct supervisory authority" over nonlawyer assistants for purposes of Rules 5.3(b) and (c)(2), and what obligations such authority entails; and (e) whether lawyers' liability under Rule 5.3 is direct or vicarious. These issues are addressed below.

\section{A. Identifying Nonlawyer Assistants}

When deciding whether to apply Rule 5.3 in evaluating a lawyer's conduct, it is first necessary to determine whether the subject assistant should be categorized as a nonlawyer. This exercise seems unnecessary until one considers that lawyers and law firms frequently employ people with law degrees who do not practice law. A person who holds a law degree and has been admitted to the bar but who is not practicing law is a lawyer, and thus a lawyer's supervisory responsibility for the person ought to be controlled by Rule 5.1. ${ }^{35}$ In contrast, a lawyer whose license is suspended is considered a nonlawyer and therefore falls under Rule

33. Of course, a lawyer who learns of an assistant's misconduct after the fact but while its consequences may be avoided or mitigated may have a duty to take reasonable remedial action. MOdEL Rules of PROF’L CONDUCT R. 5.3(c)(2) (2012).

34. See, e.g., In re Geiger, 27 So. 3d at 285 (concluding that lawyer violated Louisiana Rules 5.3(a) and (b) through negligence); In re Mopsik, 902 So. 2d 991, 995-96 (La. 2005) (per curiam) (recognizing that lawyer's Louisiana Rule 5.3(b) violation was the product of negligence); In re Craig, 454 S.E.2d 314, 314-16 (S.C. 1995) (per curiam) (determining that lawyer's negligent supervision of employees violated South Carolina Rule 5.3).

35. See In re Rost, 211 P.3d 145, 154-55 (Kan. 2009) (per curiam) (holding that an inactive or retired lawyer is still a lawyer for purposes of professional regulation). But see State Bar of Ariz. Comm. on the Rules of Prof'l Conduct, Formal Op. 96-06 (1996), available at http://www.azbar.org/Ethics/EthicsOpinions/ViewEthicsOpinion?id=471 (opining that a lawyer who has been admitted to practice in another state but who is awaiting bar examination results in the forum state is a nonlawyer under Arizona Rule 5.3); Pa. Bar Ass'n Comm. on Legal Ethics \& Prof'l Responsibility, Informal Op. 94-80 (1994), 1994 WL 928052, at*1 (advising an inactive lawyer that she could work as a nonlawyer assistant to a lawyer who assumed responsibility for her conduct in accordance with Pennsylvania Rule 5.3). 
5.3. ${ }^{36}$ Disbarred lawyers are characterized as nonlawyers and similarly fall under Rule $5.3,{ }^{37}$ as are lawyers who surrender their license in the face of discipline. ${ }^{38}$ A law school graduate who has never passed a bar examination is classified as a nonlawyer. ${ }^{39}$ This would include a law school graduate hired as a lawyer but who has yet to pass a bar examination, as well as a person with a law degree who does not intend to practice. Law students serving as interns, law clerks, or summer associates are nonlawyers for Rule 5.3 purposes, as well. ${ }^{40}$

As for why it is necessary to distinguish lawyers and nonlawyers given the nearly identical language and operative effect of Rules 5.1 and 5.3, the answer lies in the heightened supervisory obligations imposed on lawyers where nonlawyer assistants are concerned, despite the similarity of the rules. This may appear odd in the case of assistants who have formal legal education or training, but it seems more likely than not that assistants with legal education or training who are not employed as lawyers generally (1) lack the experience that would support the lighter supervision typically afforded lawyers; (2) have responsibilities or roles materially different from those usually held or filled by lawyers; or (3) are in nonlawyer roles because they are somehow unfit, unsuited, or unqualified to practice as lawyers. Regardless, a different level or scope of supervision is in order.

\section{B. The Nature and Scope of Covered Relationships}

After deciding whether a person for whose conduct a lawyer is allegedly responsible qualifies as a nonlawyer assistant, the next question is whether the assistant is "employed or retained by or associated with" the lawyer. ${ }^{41}$ There should be no debate over lawyers' duty to supervise

36. Neb. State Bar Ass'n Lawyers Adv. Comm., Advisory Op. No. 11-01, at 5 (2011) [hereinafter Neb. Op. No. 11-01], available at http://www.supremecourt.ne.gov/professionalethics/lawyers/ethics-pdfs/2000s/11-01.pdf; Pa. Bar Ass'n Comm. on Legal Ethics \& Prof'l Responsibility, Informal Op. 93-92B (1993), 1993 WL 851212, at*1.

37. In re Juhnke, 41 P.3d 855, 859-60 (Kan. 2002) (per curiam); In re Comish, 889 So. 2d 236, 244-45 (La. 2004) (per curiam); Neb. Op. No. 11-01, supra note 36, at 5.

38. Neb. Op. No. 11-01, supra note 36, at 5.

39. See Restatement (THIRD) OF THE LAW GOVERNing LAWYERS § 1 (2000) (stating that a person becomes a lawyer "[u]pon admission to the bar of any jurisdiction").

40. Copeland v. D.C. Dep’t of Emp’t Servs., 3 A.3d 331, 336 \& n.15 (D.C. 2010); Stewart v. Bee-Dee Neon \& Signs, Inc., 751 So. 2d 196, 207 n.4 (Fla. Dist. Ct. App. 2000); Att'y Grievance Comm'n of Md. v. Jaseb, 773 A.2d 516, 524 (Md. 2001); Utah State Bar Ethics Adv. Op. Comm., Adv. Op. 11-03 (2011), 2011 WL 6143437, at *1-2.

41. Model Rules of Prof'L CONDUCt R. 5.3 (2012). 
their employees. As the quoted language makes clear, however, lawyers' supervisory responsibilities are generally broader than that and encompass independent contractors who assist them, ${ }^{42}$ such as computer or information technology consultants, ${ }^{43}$ independent or freelance paralegals, ${ }^{44}$ interpreters or translators, ${ }^{45}$ investigators, ${ }^{46}$ or title abstractors. ${ }^{47}$ Lawyers generally cannot escape discipline under Rule 5.3 on the ground that an errant assistant was an independent contractor rather than an employee. ${ }^{48}$

In re Flack ${ }^{49}$ illustrates the potential reach of Rule 5.3. In that case, lawyer Stephen Flack entered into an agreement with ALMS, Ltd., whereby ALMS representatives sent mass mailings to targeted Kansas and Missouri residents promoting Flack's estate planning services. ${ }^{50}$ ALMS representatives spoke with people who responded to the mailings and used Flack's name in conducting interviews, explaining the documents to be prepared and services to be provided, and enlisting clients and collecting fees. ${ }^{51}$ ALMS employees prepared all will, trust, power of attorney, and other documents in Flack's name. ${ }^{52}$ None of the ALMS representatives were lawyers. ${ }^{53}$ Flack knew that the ALMS representatives were conducting these activities in his name, even though he did not know the names of the people on ALMS's mailing list; in fact, he did not learn his clients' identities until after they had been enlisted by

42. Conn. Bar Ass'n Comm. on Prof'l Ethics, Informal Op. 98-26 (1998), 1998 WL 988216, at *3; Pa. Bar Ass'n Comm. on Legal Ethics \& Prof'l Responsibility, Formal Op. 98-75 (1998), 1998 WL 988168, at *1 [hereinafter Pa. Eth. Op. 98-75].

43. ABA Comm. on Ethics \& Prof'l Responsibility, Formal Op. 95-398, at 1-2 (1995); Pa. Bar Ass'n Comm. on Legal Ethics \& Prof'l Responsibility, Informal Op. 2005-105 (2005), 2005 WL 2291093, at *1; Vt. Bar Ass'n, Adv. Ethics Op. 2003-03, at 3 (2003).

44. State Bar of Ariz. Comm. on Rules of Prof'l Conduct, Formal Op. 98-08, at 2-3 (1998); S.C. Bar Ethics Advisory Comm., Ethics Adv. Op. 96-13 (1996), 1996 WL 1101751, at *1.

45. Ill. State Bar Ass'n, Adv. Op. 03-07 (2004), 2004 WL 3684087, at*2.

46. D.C. Bar Legal Ethics Comm., Op. 321 (2003); State Bar of Mich. Standing Comm. on Prof'l \& Judicial Ethics, Op. RI-315 (1999), 1999 WL 33135105, at *3.

47. N.C. State Bar, 99 Formal Op. 6 (1999), 1999 WL 33262183, at *1.

48. See Model Rules of Prof'L Conduct R. 5.3 cmt. 2 (2012) (explaining that nonlawyer assistants who are independent contractors nonetheless "act for the lawyer in rendition of the lawyer’s professional services”); see, e.g., People v. Calvert, 280 P.3d 1269, 1282-83 (Colo. 2012) (rejecting lawyer's defense that paralegal was a "rogue" who engaged in the unauthorized practice of law on behalf of her own company in concluding that lawyer violated Colorado Rule 5.3(b)).

49. 33 P.3d 1281 (Kan. 2001) (per curiam).

50. Id. at 1283 .

51. Id. ALMS representatives collected a \$1,995 attorney’s fee from each client; of that fee, Flack paid \$1,745 to ALMS. Id.

52. Id.

53. Id. 
ALMS and paid the requested fee. ${ }^{54}$ Once ALMS completed the various estate planning documents, it sent them to Flack. ${ }^{55}$ Suffice it to say that Flack "exercised little or no supervision" over the ALMS representatives acting on his behalf. ${ }^{56}$

Regrettably, ALMS representatives defrauded several clients. ${ }^{57}$ Kansas disciplinary authorities charged Flack with violating Kansas Rules 5.3(b) and (c) as a result. ${ }^{58}$ A disciplinary panel concluded that Flack violated the Rules by failing to supervise the ALMS representatives and neglecting to ensure that their activities were compatible with his professional obligations as a lawyer. ${ }^{59}$ The Kansas Supreme Court ultimately agreed and suspended Flack from practice for six months, followed by a two-year period of probation and intense practice supervision. $^{60}$

It is easy to discount the decision in In re Flack as the foreseeable consequence of a harebrained business development scheme. The case is instructive, however, in that the court easily held the lawyer accountable for the misconduct of an independent contractor and its employees. ${ }^{61}$ The fact that Flack did not control the details of the ALMS representatives' activities was no bar to discipline under Rule 5.3. ${ }^{62}$

Although it is relatively easy to gauge whether a lawyer employed or retained a nonlawyer assistant, it is harder to evaluate relationships in which a lay assistant might reasonably be characterized as being "associated with" a lawyer for purposes of Rule 5.3. ${ }^{63}$ This third category of lawyer-assistant relationships could be read to include typical employer-employee and independent contractor arrangements, but it must extend beyond those or else the "associated with" language in the Rule is superfluous. ${ }^{64}$ A person might foreseeably be associated with

\footnotetext{
54. Id.

55. Id.

56. Id.

57. Id. at $1283-85$.

58. Id. at 1288.

59. Id. at 1287.

60. Id. at $1290-91$.

61. See id.

62. See id. at 1288-89 (noting that client disclosures and consents in the forms used by ALMS did not relieve Flack of his duties under rules of professional conduct).

63. See generally S.C. Bar Ethics Advisory Comm., Adv. Op. 05-12 (2005), 2005 WL 1704511 , at *4 (stating that “[a]ssociation” as used in Rule 5.3 "does not mean direct employment”).

64. Courts interpret ethics rules according to the same principles that govern statutory interpretation. Rubsenstein v. Statewide Grievance Comm., No. CV020516965S, 2003 WL 21499265, at*3 (Conn. Super. Ct. June 10, 2003) (citing Doe v. Conn. Bar Exam'g Comm., 818
} 
a lawyer for Rule 5.3 purposes where (1) the lawyer asks the person to assist with a project or task related to the lawyer's practice but does not compensate the person; (2) the person is employed by the lawyer's client, and the client assigns or instructs the person to assist the lawyer in the representation; or (3) the person offers to assist the lawyer in an aspect of the lawyer's practice and the lawyer accepts the offer. In In re Cline, ${ }^{65}$ for example, the Louisiana Supreme Court applied Rule 5.3 to a lawyer's supervision of a client who offered to assist the lawyer in completing the settlement of the client's case.

Leonard Cline represented Patsy Allday in a personal injury matter. ${ }^{66}$ Allday had previously been represented in the case by Morris Bart. ${ }^{67}$ When Cline settled the case, the insurer paying the settlement, State Farm, included Bart as a payee on the two settlement drafts. ${ }^{68}$ Allday did not want to wait for Cline to obtain Bart's signature on the drafts, so she offered to take them to Bart's office to obtain his endorsement. ${ }^{69}$ Cline "saw nothing wrong with this proposal."70 Allday returned with the two drafts ostensibly bearing Bart's signature, and Cline deposited the drafts into his trust account. ${ }^{71}$ In fact, Bart's signature was forged. ${ }^{72}$ Allday unconvincingly denied any role in the forgery. ${ }^{73}$ Louisiana disciplinary authorities charged Cline with violating Louisiana Rule 5.3(b), and the case ultimately reached the Louisiana Supreme Court. ${ }^{74}$

Cline admitted that he delegated authority for obtaining Bart's signatures on the two settlement drafts to Allday, while acknowledging that this "was a deviation from his normal office procedures."75 The court observed that Cline had failed to take even "minimal steps" to ensure that the drafts were appropriately transmitted to Bart for his

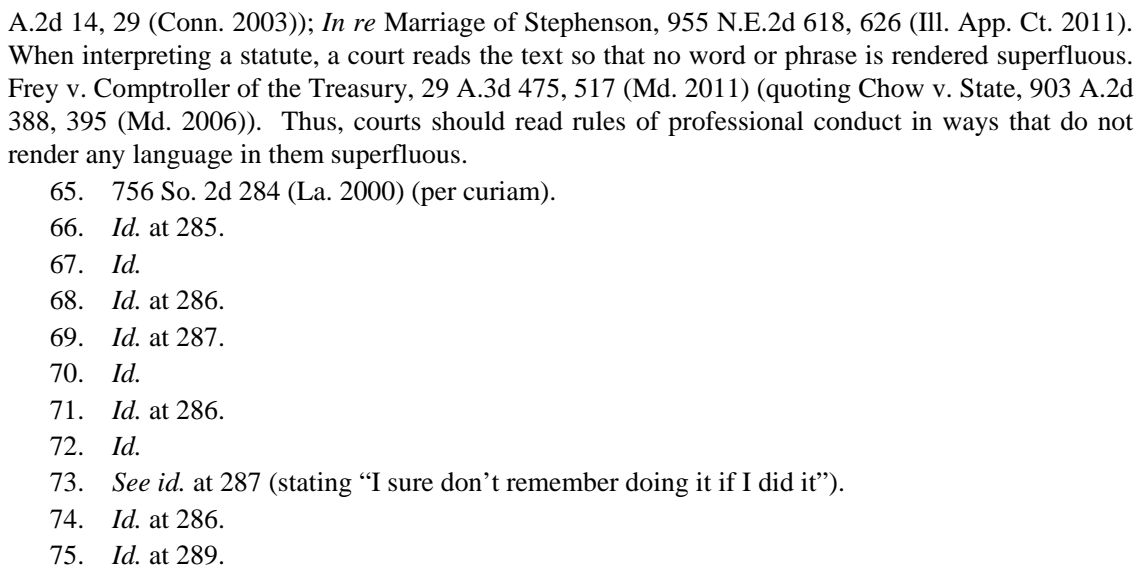


endorsement, such as calling Bart to tell him that Allday was en route to his office with the drafts. ${ }^{76}$ It was clear that Cline had not made reasonable efforts to safeguard the settlement drafts he entrusted to Allday and that, in doing so, he violated the Rule 5.3(b) mandate "that with respect to a non-lawyer employed, retained or associated by the lawyer, a lawyer must make 'reasonable efforts to ensure that the person's conduct is compatible with the professional obligations of the lawyer." "77 Based on Cline's disciplinary history, the court suspended him from practice for six months with three months deferred, rather than issuing a public reprimand-the ordinary sanction for a Rule 5.3 violation. $^{78}$

The In re Cline holding is understandable. Allday was not Cline's employee, nor did he retain her for the purpose of obtaining Bart's signatures on the drafts. She was, however, properly described as being associated with him in the task of obtaining Bart's endorsements on the settlement drafts. The case is unusual because Allday was Cline's client as well as his assistant for a discrete purpose, but the result would have been the same had someone else volunteered her services as a courier and then forged Bart's name on the drafts for some reason.

\section{The Structural Requirement of Rule 5.3(a)}

As noted earlier, clients who hire lawyers to represent them understand that lawyers must delegate some work to nonlawyers, but they expect their lawyers to ensure that delegated work is done right. Courts and disciplinary authorities recognize that lawyers must rely on nonlawyer assistants in their practices, but they also appreciate the potential for associated misconduct and know that sound policies, practices, and procedures reduce this possibility. Model Rule 5.3(a) accordingly provides that:

A partner [in a law firm], and a lawyer who individually or together with other lawyers possesses comparable managerial authority in a law firm shall make reasonable efforts to ensure that the firm has in effect measures giving reasonable assurance that the person's conduct is compatible with the professional obligations of the lawyer.

\footnotetext{
76. Id.

77. Id. (quoting LA. RULES OF PROF'L CONDUCT R. 5.3(b)).

78. Id. at 289-90.

79. Model Rules of Prof’L CONDUCt R. 5.3(a) (2012).
} 
Although Rule 5.3(a) refers to partners in law firms, it applies equally to shareholders in firms organized as professional corporations, members in firms organized as limited liability companies, lawyers practicing as sole proprietors or in other forms of association, and comparable lawyers in government agencies, legal services organizations, and corporate law departments. ${ }^{80}$ In short, the Rule requires lawyers with managerial authority to structure their firms or practices to reasonably assure professionally responsible behavior by nonlawyer assistants. ${ }^{81}$ It is the lawyer, not the lawyer's staff, who is ultimately responsible for the competent representation of clients. ${ }^{82}$

Partners who fail to structure their firms or practices to reasonably assure that nonlawyer assistants perform their duties compatibly with the partners' professional obligations violate Rule 5.3(a), even in the absence of misconduct by an assistant. ${ }^{83}$ The chance that disciplinary authorities would charge a violation in that circumstance is remote, but it is possible. ${ }^{84}$ Conversely, partners who appropriately structure their firms or practices fulfill their Rule 5.3(a) obligations even though an assistant errs or commits misconduct. ${ }^{85}$ Compliance with the structural requirements of Rule 5.3(a), however, is not a cure-all. Lawyers who have fulfilled their duties under Rule 5.3(a) nonetheless may be charged with violating Rule 5.3(b) or (c) if they fail in their role as direct supervisors. $^{86}$ Moreover, lawyers who instruct assistants to behave unethically or who ratify assistants' misconduct clearly violate Rule 5.3(a) in addition to Rule 5.3(b) or (c). ${ }^{87}$ Indeed, it is difficult to imagine a more fundamental structural failure.

80. See id. R. 1.0(c) (explaining "firm" and "law firm" terminology in the Model Rules)

81. See Nathan M. Crystal, Ethical Obligations in Using Paralegals, 21 S.C. LAW. 8 , 8 (2009) (describing Rule 5.3(a) as imposing a "structural obligation").

82. In re Montoya, 266 P.3d 11, 23 (N.M. 2011) (per curiam); Walker v. State, 723 S.E.2d 610, 615 (S.C. Ct. App. 2012) (discussing a lawyer's duties without reference to Rule 5.3).

83. 2 HAZARD \& HODES, supra note 22, § 44.4, at 44-4.1.

84. See Julie R. O’Sullivan, Professional Discipline for Law Firms? A Response to Professor Schneyer's Proposal, 16 Geo. J. Legal Ethics 1, 8 (2002) (stating that while lawyers may be disciplined for failing to implement reasonable internal controls even if no other ethics breach has yet occurred, in practice, the Rule 5.3(a) prophylactic standard is enforced only when other rules are also violated).

85. See, e.g., People v. Smith, 74 P.3d 566, 571 (Colo. 2003) (dismissing alleged Colorado Rule 5.3(a) violation where lawyer had measures in place to reasonably assure that he was made aware of all communications with his office but his legal assistant did not follow them).

86. Id. at 571-72; Att'y Grievance Comm'n of Md. v. Glenn, 671 A.2d 463, 470-72, 478-79 (Md. 1996).

87. Cincinnati Bar Ass’n v. Lawson, 891 N.E.2d 749, 758 (Ohio 2008) (per curiam). 
So what policies or procedures must a lawyer or law firm adopt or institute to comply with Rule 5.3(a)? The answer depends on the circumstances. $^{88}$ Law firms and law practices are not uniform. Reasonable measures for any firm must factor in the firm's "size, structure, nature of practice, and legal constraints, as well as the foreseeability of particular kinds of supervisory issues arising., Generally, lawyers must take steps to ensure that nonlawyer assistants are competent, diligent in adhering to deadlines and performing other responsibilities in serving clients, avoid conflicts of interest, appropriately handle client and law firm funds, and appropriately bill their time if they are timekeepers. ${ }^{90}$ Lawyers must further ensure that nonlawyer assistants understand confidentiality obligations, communicate honestly with clients and others, and avoid the unauthorized practice of law. ${ }^{91}$ Lawyers who typically represent plaintiffs in litigation should implement policies and procedures to ensure that staff members act compatibly with the lawyers' professional duties concerning settlements. ${ }^{92}$ Regardless of the specific firm or practice type, the first step in this process is thoughtful pre-employment or pre-retention interviewing and careful scrutiny of candidates for positions. $^{93}$

Can it truly be that all partners in a law firm are responsible for making reasonable efforts to ensure that the firm implements measures to reasonably assure that nonlawyer assistants act compatibly with the lawyers' professional obligations? The text of Model Rule 5.3(a) supplies an affirmative answer to this question, but the requirement is not as onerous as it initially appears. First, the extent of this duty "corresponds to the lawyer's practical ability to know matters and effect appropriate changes within the firm." "94 Thus, the two partners who comprise the entire partnership of a small law firm rightfully bear equal responsibility for erecting and maintaining their firm's ethical structure, while rank-and-file partners in a large law firm with multiple offices owe

88. 2 HAZARD \& HODES, supra note 22, § 44.4, at 44-4.1.

89. RESTATEMENT (THIRD) OF THE LAW GOVERNING LAWYERS $§ 11 \mathrm{cmt}$. g (2000).

90. Id.

91. Pa. Eth. Op. 98-75, supra note 42, at *2-4.

92. See, e.g., Ky. Bar Ass’n v. Mills, 318 S.W.3d 89, 93 (Ky. 2010) (disbarring lawyer for violating Kentucky Rule 5.3(a), among many other violations).

93. See 2 HAZARD \& HodES, supra note 22, § 44.4, at 44-4.1 (stating that "[c]ertainly, new personnel must be interviewed carefully prior to employment”).

94. RESTATEMENT (THIRD) OF THE LAW GOVERNING LAWYERS § $11 \mathrm{cmt}$. g (2000). 
substantially more limited duties. ${ }^{95}$ Second, partners may delegate their supervisory responsibilities under Rule 5.3(a) to other lawyers-such as managing partners, management committees, or practice group leadersor to nonlawyers - such as law firm administrators or office managerswhom the partners reasonably believe are capable of fulfilling them. ${ }^{96}$ Naturally, nonlawyers in supervisory roles must be appropriately supervised. ${ }^{97}$ And, if a lawyer or nonlawyer to whom such responsibilities were delegated were to prove incapable of fulfilling them, the partners would have to take reasonable remedial measures. ${ }^{98}$

Law firm leaders must take their Rule 5.3 duties especially seriously, as five related cases from Louisiana illustrate. The five lawyers in those cases comprised the management committee of Breazeale, Sachse \& Wilson, L.L.P. (BSW), a Baton Rouge law firm with over seventy lawyers. ${ }^{99}$ The factual basis for the lawyers' discipline was bizarre. A nonlawyer employee who was responsible for the content of BSW's website indicated on the website that former Louisiana Governor Murphy J. Foster, Jr., was a partner in BSW and a member of the firm's government relations practice. ${ }^{100}$ Actually, Foster had no affiliation with BSW and was not licensed to practice in Louisiana, making the related material on the website deceptive, false, and misleading. ${ }^{101}$ The

95. New Jersey and New York impose supervisory obligations on law firms, not just partners, and thus a large law firm in those states might be disciplined for a Rule 5.3(a) violation even though no individual partner is disciplined. See N.J. Rules OF Prof'L Conduct R. 5.3(a) (2004) (stating that "every lawyer, law firm or organization authorized by the Court Rules to practice law in this jurisdiction shall adopt and maintain reasonable efforts to ensure that the conduct of nonlawyers retained or employed by the lawyer, law firm or organization is compatible with the professional obligations of the lawyer ....”); N.Y. RULES OF PROF’L CONDUCT R. 5.3(a) (2009) (“A law firm shall ensure that the work of nonlawyers who work for the firm is adequately supervised, as appropriate.”). Law firm discipline, however, is rare. See Ted Schneyer, On Further Reflection: How "Professional Self-Regulation" Should Promote Compliance With Broad Ethical Duties of Law Firm Management, 53 ARIZ. L. REV. 577, 613 \& n.191 (2011) (reporting that since 1997, law firms have been publicly disciplined in four New Jersey cases and one New York case, and have been privately admonished in two New York cases).

96. RESTATEMENT (THIRD) OF THE LAW GOVERNING LAWYERS § $11 \mathrm{cmt}$. d (2000).

97. See Att’y Grievance Comm'n of Md. v. Johnson, 976 A.2d 245, 266 (Md. 2009) (rejecting lawyer's defense that he could not be held to have violated Maryland Rule 5.3 in connection with employee's dishonesty because the employee held a supervisory position).

98. RESTATEMENT (THIRD) OF THE LAW GOVERNING LAWYERS $§ 11 \mathrm{cmt}$. d (2000).

99. About Us, BREAZEALE, SACHSE \& WILSON, L.L.P., http://www.bswllp.com/solutions/ solutions.asp (last visited Sept. 19, 2012) (providing an overview of the firm).

100. In re Bursavich, 45 So. 3d 1029, 1029 (La. 2010) (per curiam); In re Charlton, 45 So. 3d 1027, 1027 (La. 2010) (per curiam); In re Foster, 45 So. 3d 1026, 1027 (La. 2010) (per curiam); In re Oubre, 45 So. 3d 1028, 1028 (La. 2010) (per curiam); In re Reynaud, 45 So. 3d 1028, 1029 (La. 2010) (per curiam).

101. In re Bursavich, 45 So. 3d at 1029-30; In re Charlton, 45 So. 3d at 1027; In re Foster, 45 
Louisiana Supreme Court publicly reprimanded all five lawyers for violating Louisiana Rule 5.3. ${ }^{102}$ The court did not specify a particular subdivision of the Rule in explaining the violations.

\section{Direct Supervisory Authority: Contours and Considerations}

While Rule 5.3(a) imposes structural obligations on partners, Rules 5.3(b) and (c)(2) regulate the conduct of lawyers who have "direct supervisory authority” over nonlawyer assistants. ${ }^{103}$ The Rules apply to lawyers with such authority even if the lawyers are themselves subordinate to other lawyers in the firm. ${ }^{104}$ To use an obvious example, law firm associates who directly supervise nonlawyer staff must comply with Rule 5.3(b) even though the associates are subordinate to the firm's partners. ${ }^{105}$ In addition, multiple lawyers may have direct supervisory authority over a single nonlawyer assistant. If, for example, a paralegal is assisting two lawyers with discovery or in preparing for trial, both lawyers must satisfy the Rule 5.3(b) requirements.

A finding of direct supervisory authority depends on more than the lawyer's position or status in the firm. For example, a partner who never works with a particular nonlawyer assistant does not have direct supervisory authority over the assistant notwithstanding the partner's status. ${ }^{106}$ On the other hand, a lawyer need not be a nonlawyer assistant's day-to-day supervisor for Rules 5.3(b) and (c)(2) to apply. ${ }^{107}$ In short, whether a lawyer possesses direct supervisory authority over a nonlawyer assistant is a case-specific question of fact. ${ }^{108}$

Lawyers may violate Rule 5.3(b) in connection with misconduct by nonlawyer assistants they supervise even if they are unaware of the

So. 3d at 1027; In re Oubre, 45 So. 3d at 1028; In re Reynaud, 45 So. 3d at 1029.

102. In re Bursavich, 45 So. 3d at 1030; In re Charlton, 45 So. 3d at 1028; In re Foster, 45 So. 3d at 1027; In re Oubre, 45 So. 3d at 1028; In re Reynaud, 45 So. 3d at 1029.

103. Model Rules of Prof'L Conduct R. 5.3(b), (c)(2) (2012). Rule 5.3(c)(2) also applies to lawyers who are partners or who have comparable managerial authority in their law firms. Id. R. 5.3(c)(2).

104. 2 HAZARD \& HODES, supra note 22, § 44.7, at 44-6.

105. See S.C. Bar Ethics Adv. Comm., Adv. Op. 06-05 (2006), 2006 WL 4666947, at *2-3 (referring to an associate working for a law firm's sole owner).

106. See id. (discussing potential supervisory responsibilities of a sole owner of a law firm with respect to supervision of a bookkeeper by the owner or by an associate).

107. Cf. In re Anonymous Member of the S.C. Bar, 552 S.E.2d 10, 13 (S.C. 2001) (per curiam) (discussing lawyers' duties under South Carolina Rule 5.1(b), which analogously refers to a lawyer "having direct supervisory authority over another lawyer").

108. See id. (discussing direct supervisory authority for South Carolina Rule 5.1 purposes). 
misconduct. ${ }^{109}$ For that matter, because Rule 5.3(b) requires a lawyer with direct supervisory authority over a nonlawyer assistant to make reasonable efforts to ensure that the assistant acts compatibly with the lawyer's professional obligations, the lawyer may be disciplined for supervisory shortcomings even if the assistant commits no misconduct. ${ }^{110}$ In this way Rule 5.3(b) is similar to Rule 5.3(a) - both impose preventive, or prophylactic, duties on lawyers. ${ }^{111}$

Under Rule 5.3(b), a lawyer with direct supervisory authority over a nonlawyer assistant must make "reasonable efforts to ensure that the person's conduct is compatible with" the lawyer's professional obligations. ${ }^{112}$ Whether a lawyer's efforts are reasonable depends on the circumstances. Different practice areas, assignments, or responsibilities will almost certainly raise different concerns or levels of concern for lawyers, just as assistants' individual experience and work history will influence the supervision required. Generally, to satisfy the reasonable effort requirement, lawyers must appropriately instruct nonlawyer assistants on professional responsibility aspects of assignments. ${ }^{113} \mathrm{~A}$ lawyer's failure to train an assistant will support a Rule 5.3(b) violation. ${ }^{114}$ Absent evidence that an assistant is contemplating particular misconduct, however, a lawyer has no duty to instruct the assistant on professional responsibilities that should be obvious to an average person. ${ }^{115}$ Apart from the general requirement that lawyers provide

109. See, e.g., People v. Calvert, 280 P.3d 1269, 1283 (Colo. 2012) (explaining that lawyer could have learned of paralegal's misconduct through “[b]asic oversight and simple diligence," but even if he had "no inkling” of the paralegal's misconduct, he still would have violated Rule 5.3(b) by inadequately supervising her work); In re Wilkinson, 805 So. 2d 142, 144-47 (La. 2002) (per curiam) (suspending lawyer for violating Louisiana Rule 5.3(b) where law clerk never told lawyer of relevant events and lawyer was otherwise unaware of them).

110. See RotUNDA \& DZIENKOWSKI, supra note 7, § 5.3-1, at 1005 (using breach of confidentiality as an example).

111. Compare Model Rules OF PROF’L CONDUCT R. 5.3(a) (2012) (stating that “a partner, and a lawyer who individually or together with other lawyers possesses comparable managerial authority in a law firm shall make reasonable efforts to ensure that the firm has in effect measures giving reasonable assurance that the person's conduct is compatible with the professional obligations of the lawyer" (emphasis added)), with id. R. 5.3(b) (providing that "a lawyer having direct supervisory authority over the nonlawyer shall make reasonable efforts to ensure that the person's conduct is compatible with the professional obligations of the lawyer" (emphasis added)).

112. Id. R. 5.3(b).

113. In re Comish, 889 So. 2d 236, 245 (La. 2004) (per curiam).

114. In re Kellogg, 4 P.3d 594, 602 (Kan. 2000) (per curiam).

115. See, e.g., Statewide Grievance Comm. v. Pinciaro, No. CV 970396643S, 1997 WL 155379, at *3 (Conn. Super. Ct. Mar. 21, 1997) (dismissing alleged Connecticut Rule 5.3(b) violation where to rule otherwise would have required the lawyer to advise the assistant at the time of hiring that it is improper to accept kickbacks from clients unless the lawyer was on notice that the assistant was 
nonlawyer assistants appropriate training or instruction, it is impossible to specify what further measures the lawyer needs to take without knowing the facts of the particular case. The essential guideline for lawyers is, as the language of the rule indicates, reasonableness. ${ }^{116}$ As the District of Columbia Court of Appeals cogently observed:

Responsible supervision does not mean that the lawyer must duplicate the employee's work or scrutinize and regulate it so closely that the economic and other advantages of the delegation are lost. Rule 5.3(b) requires "reasonable efforts," not overkill. Reasonable controls and review need not be overly intricate or unduly burdensome. ${ }^{117}$

For a lawyer with direct supervisory authority over a nonlawyer assistant to violate Rule 5.3(b), the lawyer must somehow fail as a supervisor; there is no violation if the lawyer reasonably attempts to ensure that the assistant's conduct comports with the lawyer's professional obligations but the assistant nonetheless crosses a line. ${ }^{118}$ Supervisory lawyers are not guarantors of their assistants' conduct. Lawyers, however, may not defend against alleged Rule 5.3(b) or (c)(2) violations on the basis that they were too busy to fulfill their related responsibilities, or that any failure was mere negligence. ${ }^{119}$

As discussed in connection with Rule 5.3(a), partners in leadership roles must embrace their supervisory obligations. ${ }^{120}$ A Delaware case, In re Bailey, ${ }^{121}$ indicates that law firm leaders' or managers' conduct may be subject to heightened scrutiny in evaluating the reasonableness of their supervisory efforts under Rule 5.3(b) —at least where client or firm funds are concerned. ${ }^{122}$

contemplating such misconduct).

116. See Model Rules of Prof'L Conduct R. 5.3(b) (2012) (referring to "reasonable efforts" by supervisory lawyers); id. R. 5.3(c)(2) (requiring "reasonable remedial action" by partners and supervisory lawyers in certain circumstances).

117. In re Cater, 887 A.2d 1, 16 (D.C. 2005).

118. See, e.g., People v. Peters, 82 P.3d 389, 394-95 (Colo. 2003) (rejecting alleged Colorado Rule 5.3(b) violation where lawyer reasonably instructed and supervised process server who, it turned out, had not always effected service as represented and required); In re Tos, 576 A.2d 607, 614 (Del. 1990) (per curiam) (rejecting alleged Delaware Rule 5.3(b) violation where lawyer appropriately instructed law clerk who allegedly failed to obey those instructions).

119. RESTATEMENT (THIRD) OF THE LAW GOVERNING LAWYERS § $11 \mathrm{cmt}$. f (2000).

120. See supra notes 99-102 and accompanying text (using Louisiana cases to illustrate the point).

121. 821 A.2d 851 (Del. 2003) (per curiam).

122. Id. at 864-65. For more on the professional responsibilities of law firm leaders and managers, see Douglas R. Richmond, Law Firm Management \& Professional Responsibility, 9 ROGER WiLLIAMS U. L. REV. 187 (2003). 
James Bailey was the managing partner of Bailey \& Wetzel, which "had two partners, several associates, and about a dozen employees."123 As managing partner, Bailey had responsibility for the firm's accounting practices and tax compliance. ${ }^{124}$ Audits by the Delaware Lawyers' Fund for Client Protection (the Fund) revealed serious deficiencies in Bailey \& Wetzel's accounting, tax reporting, and payment practices. ${ }^{125}$ The Fund attributed the problems to the incompetence or dishonesty of Bailey \& Wetzel's former bookkeeper and to a lazy outside accountant who was embedded in Bailey \& Wetzel in a stalled effort to reconcile the firm's books. ${ }^{126}$ Delaware authorities charged Bailey with violating several ethics rules, including the state equivalent of Rule 5.3(b). ${ }^{127}$ Bailey admitted that he violated Rule 5.3

by failing to have reasonable safeguards in place to ensure an accurate accounting of his financial books and records... , by failing to supervise his employees' conduct in reconciling his books and records and filing and paying payroll taxes, and by knowing that [the law firm's] taxes were not being timely filed and paid. ${ }^{128}$

A disciplinary board recommended that Bailey be suspended from practice for six months and one day, which he appealed to the Delaware Supreme Court. ${ }^{129}$

One of the issues on appeal was whether Bailey was guilty of knowing misconduct in connection with his stipulated failure to ensure his firm's accounting staff's compliance with the Rule 1.15 requirements for safeguarding clients' property. ${ }^{130}$ The court agreed with the Fund's assertion that a managing partner's "sustained and systematic failure" to supervise employees to ensure compliance with his duties under Rule 1.15 could not be characterized as mere negligence. ${ }^{131}$ As the court explained, a lawyer who accepts responsibility for a firm's administration "stands in a position of trust vis-à-vis other lawyers and employees."132 Managing partners must discharge their obligations

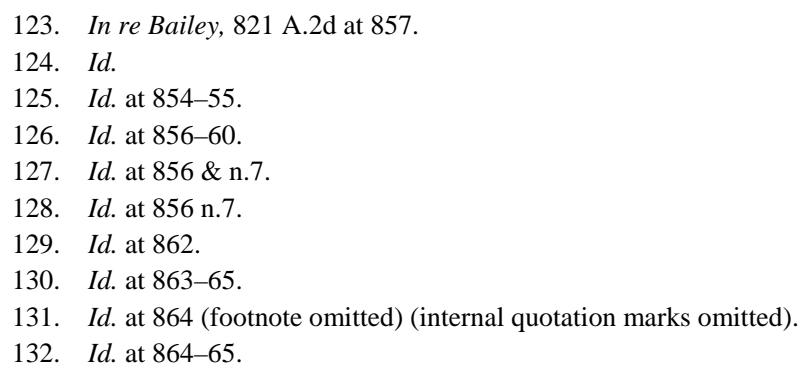


"faithfully and diligently."133 "Although a managing partner cannot guarantee, absolutely, the integrity of the firm's books and records," she must "implement reasonable safeguards to ensure that the firm is meeting its obligations with respect to its books and records." ${ }^{334}$ Meeting this requirement need not pose a substantial burden; common sense measures, such as hiring outside auditors and requiring two signatures on law firm checks, will often suffice. ${ }^{135}$ The responsibility that managing partners must shoulder, however, is a serious one. ${ }^{136}$

As for Bailey, he had "knowingly failed to exercise even a modicum of diligence” in supervising his firm's accounting practices, and his "indifference and inattention" persisted until the Fund conducted its audits. ${ }^{137}$ His knowing and sustained disregard of his duties as managing partner created the potential for serious harm to clients and colleagues. ${ }^{138}$ Even though Bailey's misconduct actually caused no serious harm, the court suspended him from practice for six months and one day as a sanction. ${ }^{139}$

\section{E. Rule 5.3 Does Not Create Vicarious Liability for Lawyers}

Perhaps the greatest concern about Rule 5.3 voiced by practicing lawyers, and a persistent misconception about the rule in general, is that it imposes vicarious liability. Rule 5.3 does no such thing. ${ }^{140}$ Lawyers' supervisory liability under Rule 5.3 is not vicarious. ${ }^{141}$ Vicarious

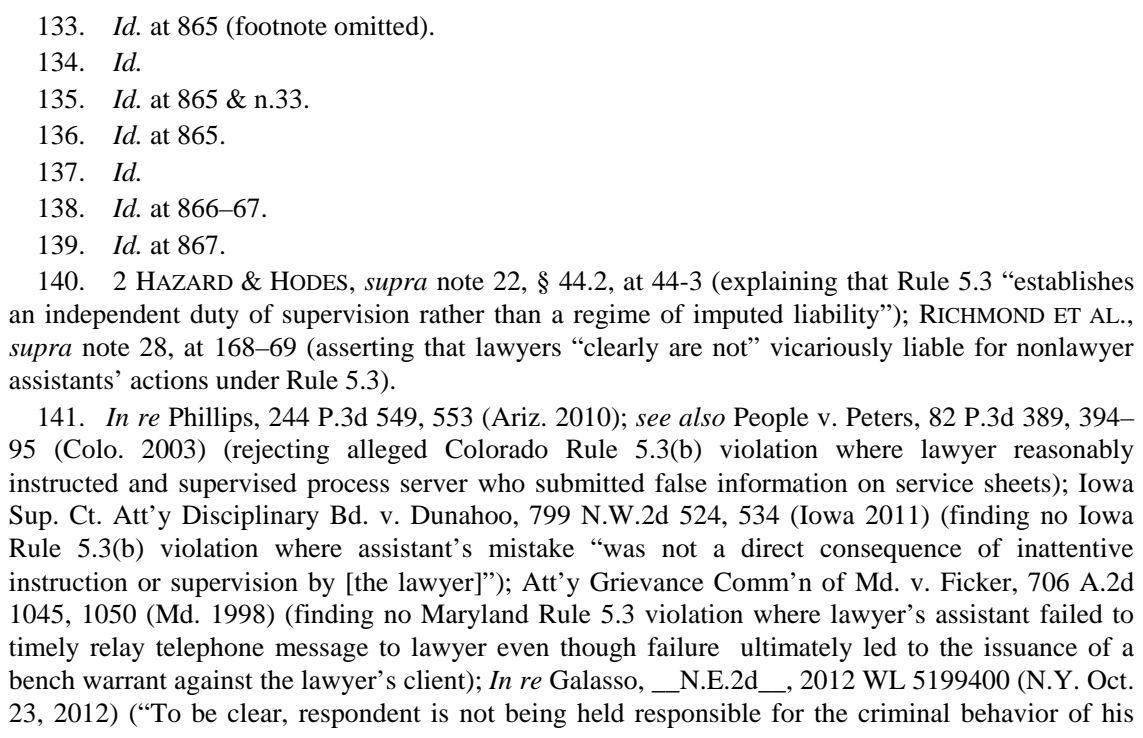

140. 2 HAZARD \& HODES, supra note 22, § 44.2, at 44-3 (explaining that Rule 5.3 "establishes an independent duty of supervision rather than a regime of imputed liability"); RICHMOND ET AL., supra note 28, at 168-69 (asserting that lawyers "clearly are not" vicariously liable for nonlawyer assistants' actions under Rule 5.3).

141. In re Phillips, 244 P.3d 549, 553 (Ariz. 2010); see also People v. Peters, 82 P.3d 389, 394 95 (Colo. 2003) (rejecting alleged Colorado Rule 5.3(b) violation where lawyer reasonably instructed and supervised process server who submitted false information on service sheets); Iowa Sup. Ct. Att'y Disciplinary Bd. v. Dunahoo, 799 N.W.2d 524, 534 (Iowa 2011) (finding no Iowa Rule 5.3(b) violation where assistant's mistake "was not a direct consequence of inattentive instruction or supervision by [the lawyer]”); Att’y Grievance Comm'n of Md. v. Ficker, 706 A.2d 1045, 1050 (Md. 1998) (finding no Maryland Rule 5.3 violation where lawyer's assistant failed to timely relay telephone message to lawyer even though failure ultimately led to the issuance of a bench warrant against the lawyer's client); In re Galasso, _N.E.2d_, 2012 WL 5199400 (N.Y. Oct. 23, 2012) ("To be clear, respondent is not being held responsible for the criminal behavior of his 
liability is liability imposed on a party for the conduct of another "based solely on a relationship between" them. ${ }^{142}$ Applying the doctrine of respondeat superior, which imposes, or produces, vicarious liability, ${ }^{143} \mathrm{a}$ principal is liable for harm occasioned by her agent's conduct in the course and scope of the agency relationship, even though the principal herself did nothing to harm the plaintiff. ${ }^{144}$ In stark contrast, applying Rule 5.3, a lawyer is not subject to discipline merely because a nonlawyer assistant errs or commits some type of misconduct in the course and scope of her work for the lawyer. ${ }^{145}$ Because the lawyer's mere relationship to the assistant furnishes no basis for discipline if the assistant acts incompatibly with the lawyer's professional duties, the lawyer's liability under Rule 5.3 is not vicarious. Rather than enforcing a vicarious liability regime, Rule 5.3 clearly imposes an independent duty of supervision. ${ }^{146}$ To violate Rule 5.3, a lawyer must somehow fail as a supervisor. ${ }^{147}$

It is also possible to illustrate that Rule 5.3 does not create vicarious liability by reverse engineering respondeat superior principles. In a nutshell, vicarious liability "is derivative and depends upon the liability of the negligent agent to the injured plaintiff." "148 If a plaintiff cannot sue the agent, the plaintiff also cannot sue the principal for vicarious liability. ${ }^{149}$ Now, someone allegedly harmed by a nonlawyer assistant's

brother. Rather, it is his own breach of his fiduciary duty and failure to properly supervise his employee, resulting in the loss of client funds entrusted to him, that warrant this disciplinary action.”).

142. Sutherland v. Barton, 570 N.W.2d 1, 5 (Minn. 1997) (quoting BLACK’s LAW DiCTIONARY 1566 (6th ed. 1990)); Affordable Power, L.P. v. Buckeye Ventures, Inc., 347 S.W.3d 825, 833 (Tex. App. 2011).

143. See Warner v. Sw. Desert Images, LLC, 180 P.3d 986, 994 (Ariz. Ct. App. 2008) (stating that "[r]espondeat superior liability is vicarious liability”); Macaluso v. Travelers Cas. \& Sur. Co., 59 So. 3d 454, 459 (La. Ct. App. 2011) (equating vicarious liability with the respondeat superior doctrine).

144. Sperl v. C.H. Robinson Worldwide, Inc., 946 N.E.2d 463, 470 (Ill. App. Ct. 2011); Fung v. Fischer, 365 S.W.3d 507, 522 (Tex. App. 2012).

145. See, e.g., Peters, 82 P.3d at 394-95 (rejecting alleged Colorado Rule 5.3(b) violation where lawyer reasonably instructed and supervised process server who submitted false information on service sheets); Dunahoo, 799 N.W.2d at 534 (finding no Iowa Rule 5.3(b) violation where assistant's mistake "was not a direct consequence of inattentive instruction or supervision by [the lawyer]”); Ficker, 706 A.2d at 1050 (finding no Maryland Rule 5.3 violation where lawyer's assistant failed to timely relay telephone message to lawyer).

146. In re Phillips, 244 P.3d at 553 (quoting In re Galbasini, 786 P.2d 971, 975 (Ariz. 1990)).

147. Id. at 553-54; see also In re Disciplinary Action Against Kaszynski, 620 N.W.2d 708, 712 (Minn. 2001) (finding a failure to supervise).

148. Morales-Cruz v. Pac. Coast Container, Inc., No. 65820-4-I, 2011 WL 3568897, at *6 (Wash. Ct. App. Aug. 15, 2011).

149. Id. 
misconduct cannot obtain relief by reporting the assistant to disciplinary authorities; such assistants are not subject to professional discipline. ${ }^{150}$ Because the assistant is immune to discipline for her alleged misconduct, it is impossible for the lawyer for whom the assistant works to be vicariously liable for violating Rule 5.3. Applying the respondeat superior doctrine, there is no basis for deriving the lawyer's disciplinary responsibility. As a result, the lawyer can be disciplined, if at all, only for some supervisory breach. That is a separate theory of responsibility. ${ }^{151}$ Although vicarious liability may work in tort, it is no basis for imposing professional discipline in any jurisdiction that has adopted Rule 5.3. ${ }^{152}$

Nonetheless, the mistaken notion that Rule 5.3 makes lawyers vicariously liable for nonlawyer assistants' misconduct persists, as State ex rel. Oklahoma Bar Ass'n v. Martin ${ }^{153}$ illustrates. The lawyer there, Jeffrey Martin, found himself in hot water because of his relationship with a nonlawyer named Mark Wingo, whom he met when Wingo approached Martin about a job. ${ }^{154}$ Wingo was on federal probation for white collar crimes and needed a job to satisfy the requirements of his probation. ${ }^{155}$ When he called on Martin, Wingo was operating a "legal support services" business in the same building as Martin, in which he supposedly did photocopying, Bates-numbering, and miscellaneous paralegal work. ${ }^{156}$ Martin agreed to put Wingo on his firm's payroll, and Wingo agreed to call his business the Jeff Martin Research Center. ${ }^{157}$ Wingo was to run the Center and bear any losses; Martin would be compensated by receiving a percentage of the Center's income. ${ }^{158}$

Martin performed no pre-employment background check on Wingo, nor did he ever attempt to learn what services Wingo was actually providing to anyone in his business. ${ }^{159}$ Martin never had any direct

150. Att'y Grievance Comm'n of Md. v. Wills, 705 A.2d 1121, 1124 (Md. 1998).

151. Compare Restatement (THIRD) OF AGENCY § 7.03(2) (2006) (outlining principal's vicarious liability for agent's conduct), with id. $\S 7.05(1)$ (governing principal's liability for negligent supervision of agent).

152. See generally 2 HAZARD \& HODES, supra note 22, § 44.2, at 44-3 (explaining that Rule 5.3 "establishes an independent duty of supervision rather than a regime of imputed liability").

153. 240 P.3d 690 (Okla. 2010).

154. Id. at 696 .

155. Id.

156. Id

157. Id.

158. Id.

159. Id. 
contact with Wingo's operations. ${ }^{160}$ When he received funds from Wingo, Martin simply assumed that they had been earned through the Center. ${ }^{161}$ In fact, Wingo was practicing law without a license. ${ }^{162}$ The Westcotts, a couple who were deceived by Wingo in connection with their son's purported representation, complained about Martin to the Oklahoma Bar Association. ${ }^{163}$ A professional responsibility tribunal found that Martin had violated several Oklahoma Rules of Professional Conduct, including Oklahoma Rule 5.3, and recommended his suspension from practice for six months. ${ }^{164}$ Martin's case then proceeded to the Oklahoma Supreme Court.

The court in Martin began its analysis by observing that lawyers are duty-bound to supervise the work done by their lay assistants and ultimately are responsible for all work done by their staffs. ${ }^{165}$ Lawyers who fail to properly supervise nonlawyer assistants are "guilty of dereliction of duty."166 In this case, Martin's "utter failure” to supervise Wingo allowed Wingo to engage in the unauthorized practice of law. ${ }^{167}$

After that introduction, the court attempted to explain Martin's violation of Rule 5.3 in greater detail. In doing so, it quickly spun a vicarious liability web:

The vicarious responsibility of a lawyer... subjects [him] both to private-law (civil) liability as well as to the Bar's disciplinary process of public law. Today's opinion deals exclusively with the respondent's breach of his public-law duty as a member of the Bar. A disciplinary dereliction that comes under the rubric of a lawyer's breach of vicarious professional responsibility may not be treated as less serious than one of the same nature which was brought to enforce a practitioner's personal disciplinary responsibility by his own act or omission. Both breaches must be dealt with as being of equal seriousness. The discipline to be imposed for these derelictions should not vary one iota if the facts are identical. We must hence look at the respondent's breach in the same light as we would if this case were here to enforce his own disciplinary offense rather than his vicarious responsibility for breach by a third party acting as respondent's agent.

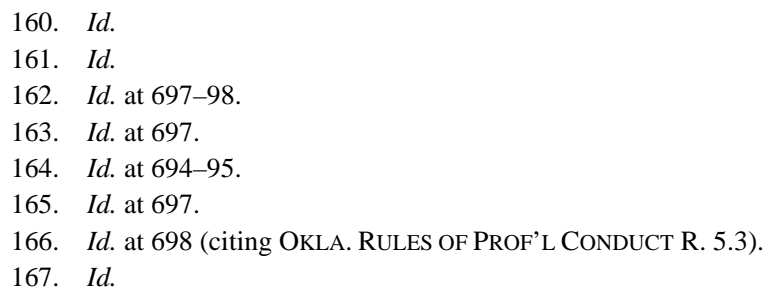


In short, although the respondent was not the actor, the act in suit is imputed in law to his own doing. ${ }^{168}$

Next, the court foreclosed any future argument that lawyers in Martin's situation might escape discipline through defenses based on their firms' organizational forms. The court adhered to its vicarious liability approach in the process:

Simply and concisely stated, a lawyer's vicarious public-law liability, in the context of a disciplinary bar proceeding, means that all licensed lawyers are fully and absolutely accountable for all breaches of professional ethics committed not only by fellow lawyers in the law firm, but also by those persons who are unlicensed or lay employees of a lawyer or of an association of lawyers in a single firm, regardless of the firm's name or of its precise legal entity.

Martin fell "woefully short" in supervising Wingo and ensuring that Wingo's conduct was compatible with Martin's obligations as a lawyer. ${ }^{170}$ Martin's dereliction of his professional duties enabled Wingo to practice law without a license and, in the process, harm the Westcotts. ${ }^{171}$ The fact that Wingo also may have victimized Martin did not reduce Martin's culpability. ${ }^{172}$ Martin was "vicariously liable in disciplinary responsibility” for all of Wingo's misdeeds, which went unnoticed until the Westcotts complained. ${ }^{173}$ In the end, the court settled on a public reprimand as Martin's discipline. ${ }^{174}$

Although Martin certainly deserved discipline for allowing Wingo to run amok, the decision in Martin is otherwise deeply flawed; the Oklahoma Supreme Court mangled the Rule 5.3 analysis. In mistakenly holding lawyers vicariously liable for their lay assistants' misconduct, the court overlooked both case law ${ }^{175}$ and respected scholarly authority ${ }^{176}$ instructing that Rule 5.3 does nothing of the sort. The court also missed the obvious analogy to Rule 5.1, which employs nearly identical

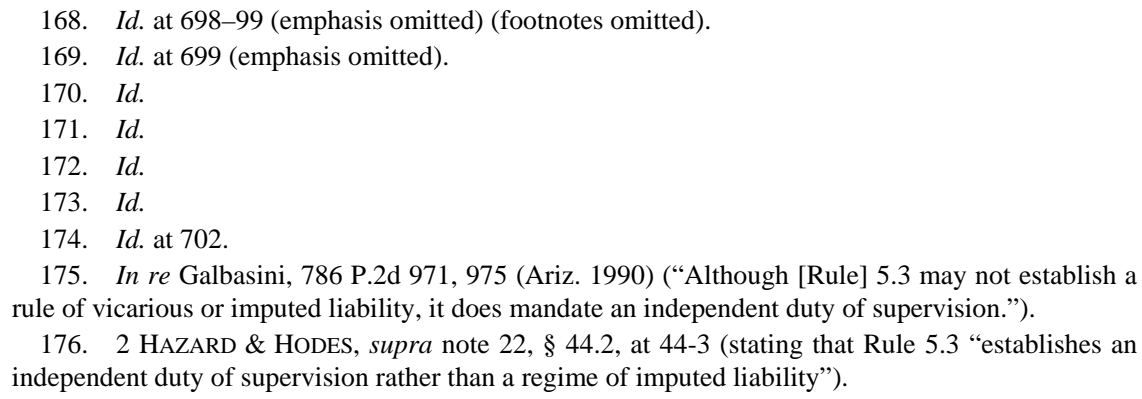

175. In re Galbasini, 786 P.2d 971, 975 (Ariz. 1990) (“Although [Rule] 5.3 may not establish a rule of vicarious or imputed liability, it does mandate an independent duty of supervision.”).

176. 2 HAZARD \& HODES, supra note 22, § 44.2, at 44-3 (stating that Rule 5.3 "establishes an independent duty of supervision rather than a regime of imputed liability"). 
language in establishing lawyers' supervisory responsibility for other lawyers, and which other courts had held did not create vicarious liability. ${ }^{177}$ Moreover, the court did not need to rely on vicarious liability to discipline Martin or, more fundamentally, to causally link Wingo's misconduct to Martin. But for Martin's inexplicable abdication of his supervisory obligations, Wingo could not have victimized the Westcotts as he did - a point the court recognized. ${ }^{178}$ In other words, the Martin court's misguided detour into vicarious liability was completely unnecessary.

To summarize, Model Rule 5.3 and equivalent state rules of professional conduct do not make lawyers guarantors of nonlawyer assistants' conduct. ${ }^{179}$ Rule 5.3 does not create vicarious liability for lawyers. ${ }^{180}$ Vicarious liability flows from the mere relationship between the alleged wrongdoer and the defendant. ${ }^{181}$ In contrast, Model Rule 5.3 and state analogs impose an independent duty of supervision on lawyers. ${ }^{182}$ In this respect, Martin was wrongly decided and other courts should not follow it.

\section{RULE 8.4(a)}

It is impossible to discuss Rule 5.3 without also giving a nod to Rule 8.4(a), given that cases in which lawyers are held to violate Rule 5.3 frequently generate Rule 8.4(a) violations as well. ${ }^{183}$ Rule 8.4(a) provides that it is professional misconduct for a lawyer to "violate or attempt to violate the Rules of Professional Conduct, knowingly assist or

177. In re Anonymous Member of the S.C. Bar, 552 S.E.2d 10, 14 (S.C. 2001) (per curiam); Stewart v. Coffman, 748 P.2d 579, 581-82 (Utah Ct. App. 1988).

178. Martin, 240 P.3d at 699.

179. In re Phillips, 244 P.3d 549, 553 (Ariz. 2010) (quoting In re Miller, 872 P.2d 661, 663 (Ariz. 1994)).

180. Id.

181. Sutherland v. Barton, 570 N.W.2d 1, 5 (Minn. 1997) (quoting BlaCK’s LAW DictionaRY 1566 (6th ed. 1990)); Affordable Power, L.P. v. Buckeye Ventures, Inc., 347 S.W.3d 825, 833 (Tex. App. 2011); 1 Ronald E. MALLEN \& JEFFREY M. SMith, LEgal MALPRACTICE § 5:8, at 663 (2009 ed.).

182. In re Phillips, 244 P.3d at 553 (quoting In re Galbasini, 786 P.2d 971, 975 (Ariz. 1990)).

183. See, e.g., In re Williams, 52 So. 3d 864, 870 (La. 2011) (per curiam) (reciting disciplinary board's finding that by violating Louisiana Rule 5.3(b), among other rules, lawyer also violated Rule 8.4(a)); In re Geiger, 27 So. 3d 280, 285 (La. 2010) (per curiam) (concluding that lawyer who violated Louisiana Rules 5.3(a) and (b) also violated Rule 8.4(a)); Martin, 240 P.3d at 698 (noting that a lawyer who violated Oklahoma Rule 5.3 also violated Rule 8.4(a)); In re Woods, 702 S.E.2d 562, 564 (S.C. 2010) (per curiam) (reprimanding lawyer who, by violating South Carolina Rule 5.3, among other rules, also violated Rule 8.4(a)). 
induce another to do so, or do so through the acts of another.”184 The second and third forms of conduct prohibited in Rule 8.4(a) have obvious implications for lawyers' use of nonlawyer assistants. Lawyers cannot instruct agents to do for them that which they cannot ethically do themselves. ${ }^{185}$ For example, lawyers cannot direct lay assistants to communicate ex parte with represented parties in circumstances where the lawyers are prohibited from doing so under Rule $4.2,{ }^{186}$ or use a nonlawyer to solicit clients when Rule 7.3 would prevent the lawyer from doing so herself. ${ }^{187}$ By way of further example, a lawyer cannot instruct or permit a nonlawyer assistant to make misrepresentations or to engage in deceitful or misleading conduct that the lawyer would be prohibited from making or engaging in under Rule 8.4(c). ${ }^{188}$

A lawyer may violate Rule 8.4(a) merely by attempting to violate another rule of professional conduct. ${ }^{189}$ The paradigmatic example of this principle is a case in which a lawyer plans or tries to do something that would violate a rule of professional conduct but is prevented from doing so or is frustrated in her effort. ${ }^{190}$ For a lawyer to be disciplined

184. Model Rules of PROF'L CONDUCT R. 8.4(a) (2012).

185. See id. R. $8.4 \mathrm{cmt} .1$ ("Lawyers are subject to discipline when they violate or attempt to violate the Rules of Professional Conduct, knowingly assist or induce another to do so or do so through the acts of another, as when they... instruct an agent to do so on the lawyer's behalf." (emphasis added)).

186. See, e.g., In re Pyle, 91 P.3d 1222, 1228-29 (Kan. 2004) (per curiam) (concluding that lawyer violated Kansas Rule 4.2 by having client deliver an affidavit to represented opposing party and that Kansas Rule 8.4(a) was embedded in Kansas Rule 4.2 in this instance); Bratcher v. Ky. Bar Ass'n, 290 S.W.3d 648, 648-50 (Ky. 2009) (reprimanding lawyer who, in representing a plaintiff in a wrongful discharge suit, hired a company to call the defendant while posing as prospective employer checking the plaintiff's references).

187. See, e.g., Miss. Bar v. Turnage, 919 So. 2d 36, 44 (Miss. 2005) (concluding that lawyer's use of former insurance agent to solicit clients violated Mississippi Rules 7.3 and 8.4(a)); In re Pajerowski, 721 A.2d 992, 995 (N.J. 1998) (per curiam) (concluding that lawyer's use of "runners" to solicit clients violated New Jersey Rules 5.3, 7.3, and 8.4(a) among other rules).

188. See, e.g., People v. Cozier, 74 P.3d 531, 536 (Colo. 2003) (concluding that lawyer who instructed notary to notarize a signature she had not witnessed and who then published the document to probate court violated Colorado Rules 8.4(a) and (c)). Rule 8.4(c) provides that it is professional misconduct for lawyers to "engage in conduct involving dishonesty, fraud, deceit or misrepresentation.” MODEL RULES OF PROF'L CONDUCT R. 8.4(c) (2012).

189. See, e.g., In re Fink, 22 A.3d 461, 469-71 (Vt. 2011) (agreeing with a professional responsibility board panel that a lawyer violated Vermont Rule 8.4(a) by attempting to charge an unreasonable contingent fee in violation of Vermont Rule 1.5(a)). But see Iowa Sup. Ct. Att'y Disciplinary Bd. v. Templeton, 784 N.W.2d 761, 769 (Iowa 2010) (stating that the purpose of Iowa Rule 8.4(a) is to notify lawyers that they are subject to discipline for violating rules of professional conduct, not to create a separate violation).

190. See, e.g., People v. Katz, 58 P.3d 1176, 1192 (Colo. 2002) (discussing a lawyer's attempt to convert funds and stating that "[t]he fortuitous discovery and frustration of [the lawyer's] intended misappropriation ... does not lessen the seriousness of his actions. Through his conduct, [the 
for knowingly assisting or inducing another person to violate a rule of professional conduct, or for a lawyer to violate an ethics rule through the acts of another, however, there must be an underlying rule violation. ${ }^{191}$ In these latter two contexts, there can be no independent Rule 8.4(a) violation; the lawyer must violate some other rule of professional conduct. $^{192}$

\section{LAWYERS’ COMMON LAW DUTY OF SUPERVISION AND RESTATEMENT SECTION 11}

In addition to evaluation under Rule 5.3, lawyers' supervisory responsibilities for nonlawyer assistants may expose them to potential civil liability to clients and others. For that matter, the prospect of tort liability is "practically of greater importance" to most lawyers than the threat of professional discipline. ${ }^{193}$ This leads us to the principles set forth in the Restatement (Third) of the Law Governing Lawyers, which "draws heavily" on case law in framing lawyers' civil liability. ${ }^{194}$ Section 11 of the Restatement combines Rules 5.1 and 5.3, closely paraphrasing them in the process. With respect to lawyers' supervision of nonlawyer assistants, section 11 provides:

(4) With respect to a nonlawyer employee of a law firm, the lawyer is subject to professional discipline if either:

(a) the lawyer fails to make reasonable efforts to ensure:

(i) that the firm in which the lawyer practices has in effect measures giving reasonable assurance that the nonlawyer's conduct is compatible with the professional obligations of the lawyer; and

(ii) that conduct of a nonlawyer over whom the lawyer has direct supervisory authority is compatible with the professional obligations of the lawyer; or

\footnotetext{
lawyer] attempted to knowingly convert funds of another in violation of [Colorado Rule 8.4(a)].”); Lawyer Disciplinary Bd. v. Duty, 671 S.E.2d 763, 770 (W. Va. 2008) (per curiam) (finding that lawyer who wrongfully but unsuccessfully attempted to withhold $\$ 3,500$ in expenses from settlement proceeds violated West Virginia Rules 8.4(a) and (c)).

191. See, e.g., Long v. Ethics \& Discipline Comm. of the Utah Sup. Ct., 256 P.3d 206, 219-20 \& n.55 (Utah 2011) (finding that because lawyer did not violate Utah Rule 5.3(a) or 5.5(a), he could not have violated Rule 8.4(a)).

192. Id. at 220 n.55.

193. RESTATEMENT (THIRD) OF THE LAW GOVERNING LAWYERS, Foreword, at XXI (2000).

194. Id.
} 
(b) the nonlawyer's conduct would be a violation of the applicable lawyer code if engaged in by a lawyer, and

(i) the lawyer orders or, with knowledge of the specific conduct, ratifies the conduct; or

(ii) the lawyer is a partner or principal in the law firm, or has direct supervisory authority over the nonlawyer, and knows of the conduct at a time when its consequences can be avoided or mitigated but fails to take reasonable remedial measures. ${ }^{195}$

Having been led this far, however, it is not easy to tie section 11 to principles of civil liability. Section 11 refers to the remedy of professional discipline and, indeed, courts have so employed it. ${ }^{196}$ Nothing in the text of the section suggests that it describes lawyers' potential civil liability for failing to supervise nonlawyer assistants. That said, three things are surely true. First, the Restatement as a whole is focused on lawyers' civil liability. ${ }^{197}$ Second, the comments to section 11 are littered with references to lawyers' civil liability. ${ }^{198}$ Third, if the reporters for the Restatement intended solely to clarify "the intendment" of Rule 5.3 or to supersede mistakes in the drafting of Rule $5.3,{ }^{199}$ it is unlikely that section 11 would so closely resemble Rule 5.3. It is therefore reasonable to conclude that section 11 has two applications: professional discipline and civil liability. In this way, section 11 is distinct from Rule 5.3, which is clearly focused on professional discipline. $^{200}$

195. Id. § 11 .

196. See, e.g., Mahoning Cnty. Bar Ass’n v. Lavelle, 836 N.E.2d 1214, 1217-18 (Ohio 2005) (invoking section 11 in disciplining lawyer for supervisory failures).

197. RESTATEMENT (THIRD) OF THE LAW GOVERNING LAWYERS, Foreword, at XXI (2000).

198. Id. $\S 11 \mathrm{cmt}$. a (referring to lawyers’ vicarious civil liability for harms caused by other lawyers, stating that a lawyer is not vicariously liable for the acts of another lawyer in a firm organized as a limited liability enterprise, and stating that a lawyer's failure to supervise may violate a lawyer's duty of care to a client); id. cmt. f (referring to lawyers' vicarious liability for the acts of nonlawyers and citing to section 58).

199. See id. at XXII ("In many instances ... the Restatement significantly departs from the code formulations. ... [M] [Mny of these departures simply clarify the intendment of the code provisions and others seek to supersede drafting mistakes.”).

200. See Model Rules of Prof'L Conduct, Scope [19] (2012) ("Failure to comply with an obligation or prohibition imposed by a Rule is a basis for invoking the disciplinary process.”). Although the Model Rules and state equivalents are focused on professional discipline, in many jurisdictions they may be used to establish the standard of care in civil litigation against lawyers. Douglas R. Richmond, Why Legal Ethics Rules Are Relevant to Lawyer Liability, 38 ST. MARY'S L.J. 929, 939, 946-60 (2007). 
It is first noteworthy that from a structural standpoint, section 11(4)(A)(i) is broader than Rule 5.3(a) because section 11(4)(A)(i) provides that all lawyers in a firm must attempt to ensure that the firm has in effect measures giving reasonable assurance that nonlawyers' conduct is compatible with lawyers' professional obligations, while Rule 5.3(a) imposes this duty only on partners and other lawyers with comparable managerial authority. ${ }^{201}$ In further contrast to Rule 5.3, but consistent with tort and agency law principles, the obligations expressed in section 11 may be understood to permit lawyers' vicarious liability for nonlawyer assistants' errors. ${ }^{202}$ This conclusion flows from reading section 11 together with section 58, the latter recognizing that law firms and lawyers may be vicariously liable for the wrongful acts or omissions of employees acting in the ordinary course and scope of the lawyer's or firm's business, or with actual or apparent authority. ${ }^{203}$ As the language makes clear, however, section 11 also reflects the common law position that lawyers owe supervisory duties regarding nonlawyer assistants, for which they may be directly liable should they breach them. ${ }^{204}$

Of course, courts in civil cases may hold lawyers vicariously liable for lay assistants' misconduct or decide negligent supervision cases against lawyers without mentioning or relying on section 11 . It is therefore important to understand lawyers' potential supervisory liability in broader context.

A defendant's vicarious liability premised on respondeat superior and liability for negligent supervision represent separate theories of recovery. ${ }^{205}$ Plaintiffs may allege both causes of action in the same

\footnotetext{
201. RESTATEMENT (THIRD) OF THE LAW GOVERNING LAWYERS § $11 \mathrm{cmt}$. f (2000).

202. See id. (referring to section 58, which is entitled "Vicarious Liability").

203. Id. § 58.

204. See, e.g., David C. Joel, Att’y at Law, P.C. v. Chastain, 562 S.E.2d 746, 750 (Ga. Ct. App. 2002) (discussing lawyer's liability to client based on lawyer's supervisory failure with respect to a nonlawyer "case negotiator").

205. Beach v. Budd, No. A10-1471, 2011 WL 1642579, at *8 n.7 (Minn. Ct. App. May 3, 2011); Tessier v. Rockefeller, 33 A.3d 1118, 1133 (N.H. 2011) (quoting Exeter Hosp. v. N.H. Ins. Guar. Ass'n, 965 A.2d 1159, 1163-64 (N.H. 2009)). Under respondeat superior, a plaintiff is not required to establish any breach of duty by the employer, while a negligent supervision claim requires the plaintiff to prove the employer's negligence proximately caused her injuries. Vancura v. Katris, 939 N.E.2d 328, 343 (Ill. 2010). In some states, liability for negligent supervision may—or even must-be premised on employee misconduct occurring outside the scope of employment. See, e.g., Dawkins v. City of Honolulu, 761 F. Supp. 2d 1080, 1093 (D. Haw. 2010) (applying Hawaii law); LaPlant v. Snohomish Cnty., No. 64281-2-I, 2011 WL 1744441, at *2 (Wash. Ct. App. May 9 , 2011) (“'A] cause of action for negligent supervision requires a plaintiff to show that an employee acted outside the scope of his or her employment. But when an employee commits negligence within the scope of employment, a different theory of liability—vicarious liability—applies.” (footnotes
} 
case. $^{206}$ Although not required for vicarious liability, plaintiffs must support negligent supervision claims against lawyers with expert testimony concerning the standard of care. ${ }^{207}$

When the concern is whether a lawyer is vicariously liable for an employee's alleged error, the questions are generally straightforward. For example, did the employee's misconduct occur in the course and scope of her employment? ${ }^{208}$ A lawyer's potential liability becomes harder to evaluate where the alleged wrongdoer is not the lawyer's employee, but instead is an independent contractor retained by or associated with the lawyer. Kleeman $v$. Rheingold ${ }^{209}$ is the leading case on this point.

Janet Kleeman retained Paul Rheingold to represent her in a medical malpractice case against Dr. Neils Lauersen. ${ }^{210}$ Rheingold sent the suit papers to Fischer's Service Bureau, the process service agency his firm regularly used, to serve Dr. Lauersen. ${ }^{211}$ The process server that Fischer's assigned to the case served Dr. Lauersen improperly, and, as a result, Kleeman's suit was barred by the statute of limitations. ${ }^{212}$ Kleeman then sued Rheingold for legal malpractice on three theories: first, that Rheingold breached a nondelegable duty owed by all lawyers to assure proper service of their clients' legal process; second, that Rheingold was liable for the process server's error under agency principles; and third, that Rheingold was directly liable for negligently selecting Fischer's to serve her suit, for failing to monitor or supervise Fischer's work, and for failing to file the summons and complaint in a fashion that would have tolled the statute of limitations. ${ }^{213}$ Rheingold won summary judgment in the trial court and a lower appellate court

omitted)). Finally, some states distinguish between negligent supervision, negligent hiring, and negligent retention claims. See, e.g., Wayman v. Accor N. Am., Inc., 251 P.3d 640, 649 (Kan. Ct. App. 2011) (quoting Marquis v. State Farm Fire \& Cas. Co., 961 P.2d 1213, 1223 (Kan. 1998)), and noting the distinct theories of recovery).

206. See, e.g., Selechnik v. Office of Howard R. Birnbach, 920 N.Y.S.2d 128, 131 (N.Y. App. Div. 2011) (concluding that the plaintiff adequately stated causes of action to recover from law firm under the doctrine of respondeat superior and on the theory of negligent hiring and retention).

207. McLister v. Epstein \& Lawrence, P.C., 934 P.2d 844, 847 (Colo. App. 1996).

208. See, e.g., Moser v. Davis, 79 S.W.3d 162, 170 (Tex. App. 2002) (holding that lawyer was not liable for legal secretary's actions where secretary was acting outside the scope of her employment).

209. 614 N.E.2d 712 (N.Y. 1993)

210. Id. at $713-14$.

211. Id. at 714

212. Id.

213. Id. 
affirmed the trial court judgment. ${ }^{214}$ Kleeman then appealed to the New York Court of Appeals, the state's highest court.

In rejecting Kleeman's claims, both the trial court and the lower appellate court had concluded that a process server is an independent contractor rather than an attorney's agent, and, as such, Rheingold could not be vicariously liable for Fischer's failure to properly serve Kleeman's suit. $^{215}$ The Court of Appeals disagreed, deciding that lawyers owe clients a nondelegable duty to accomplish service of process and cannot escape liability for breaching that duty by delegating the task to independent contractors. ${ }^{216}$

The Kleeman court reasoned that the duty owed by lawyers to their clients to exercise care in serving process fit "squarely and neatly within the category of obligations that the law regards as 'non-delegable,"” and thus qualified as an exception to the general rule that one who retains an independent contractor is not liable for the independent contractor's negligence. ${ }^{217}$ As the court explained:

Manifestly, when an individual retains an attorney to commence an action, timely and accurate service of process is an integral part of the task that the attorney undertakes... Furthermore, proper service of process is a particularly critical component of a lawyer's over-all responsibility for commencing a client's lawsuit, since a mistake or oversight in this area can deprive the client of his or her day in court.... Given the central importance of this duty... attorneys cannot be allowed to evade responsibility for its careful performance by the simple expedient of "farming out" the task to independent contractors. ${ }^{218}$

The court buttressed its conclusion with provisions of the New York Code of Professional Responsibility that prevented lawyers from prospectively limiting liability to clients, forbid lawyers from neglecting client matters, enjoined them in protecting and securing their clients' rights, and required them to zealously represent clients within the bounds of the law. ${ }^{219}$ All of these professional responsibility considerations are

\footnotetext{
214. Id.

215. Id.

216. Id

217. Id. at 716 .

218. Id.

219. Id.
} 
triggered when a lawsuit is imperiled by carelessness in serving process. ${ }^{220}$

The court further explained that its conclusion was supported by public perception and the expectations of average clients, who reasonably assume that all tasks associated with the initiation of litigation will be performed by lawyers or at their direction. ${ }^{221}$ Although it is customary for lawyers to hire independent contractors to serve process, the public is not necessarily aware of that practice. ${ }^{222}$ Even if a client knows that her lawyer will use a process server, it is unlikely she will realize that the process server's status as an independent contractor could shield the lawyer against liability for the process server's alleged negligence. ${ }^{223}$ A client's reasonable beliefs and expectations about who will perform a service are important factors in identifying nondelegable duties. ${ }^{224}$

Finally, the court concluded that permitting lawyers to shift to process servers their duty of care would contravene public policy. ${ }^{225}$ This policy was grounded in lawyers' exclusive franchise to practice law, which presumes they have the specialized knowledge and character required to represent clients competently and diligently. ${ }^{226}$ Clients must be confident that their actions will be commenced in accordance with complex procedural requirements and the "formidable body" of related case law. ${ }^{227}$ Because lawyers alone have the experience and knowledge necessary to protect clients' rights in this regard, they must bear not only attendant responsibility, but also liability for any associated negligence. $^{228}$

For these reasons, it was apparent that the lower courts erred in awarding summary judgment to Rheingold. ${ }^{229}$ If the process server's failure to serve properly the defendant in the medical malpractice action was the product of negligence, Kleeman was entitled to hold Rheingold

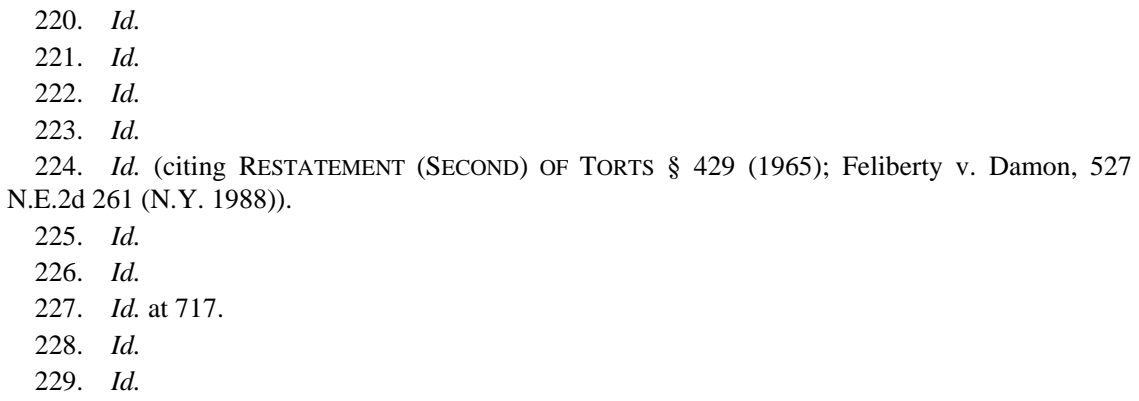


vicariously liable for that failure. ${ }^{230}$ Because it reversed the judgment in favor of Rheingold, the Court of Appeals declined to consider Kleeman's other theories of liability. ${ }^{231}$

Kleeman is a narrow decision. The court confined its recognition of a nondelegable duty of care to clients "to the discrete and unique function of commencing an action through service of process."232 That nondelegable duty logically extends to the service of subpoenas to secure witnesses' appearance at trials or other key events, but, in other cases, independent contractors' unique status will defeat imputation of liability to the lawyers that retained them. ${ }^{233}$ In the legal malpractice context, anyway, nondelegable duties are uncommon. ${ }^{234}$ In Lawyers Title Insurance Corp. v. Groff, ${ }^{235}$ for example, the New Hampshire Supreme Court determined that a lawyer was not vicariously liable for a title abstractor's negligence in performing a title search. ${ }^{236}$ The Groff court reasoned that the lawyer's alleged duty to examine and clear title "was not so essential to the representation as to render it nondelegable.",237 The court was concerned that a contrary ruling might require lawyers to guarantee the results of numerous specialists hired as independent contractors, even though they did not agree to assume this responsibility. ${ }^{238}$

An interesting question that the Kleeman court did not reach was whether Rheingold satisfied his duty of care to commence Kleeman's suit properly by retaining a licensed process server. ${ }^{239}$ In other words, was Rheingold negligent in retaining Fischer's to serve Kleeman's suit papers? The lower appellate court found that Rheingold satisfied his

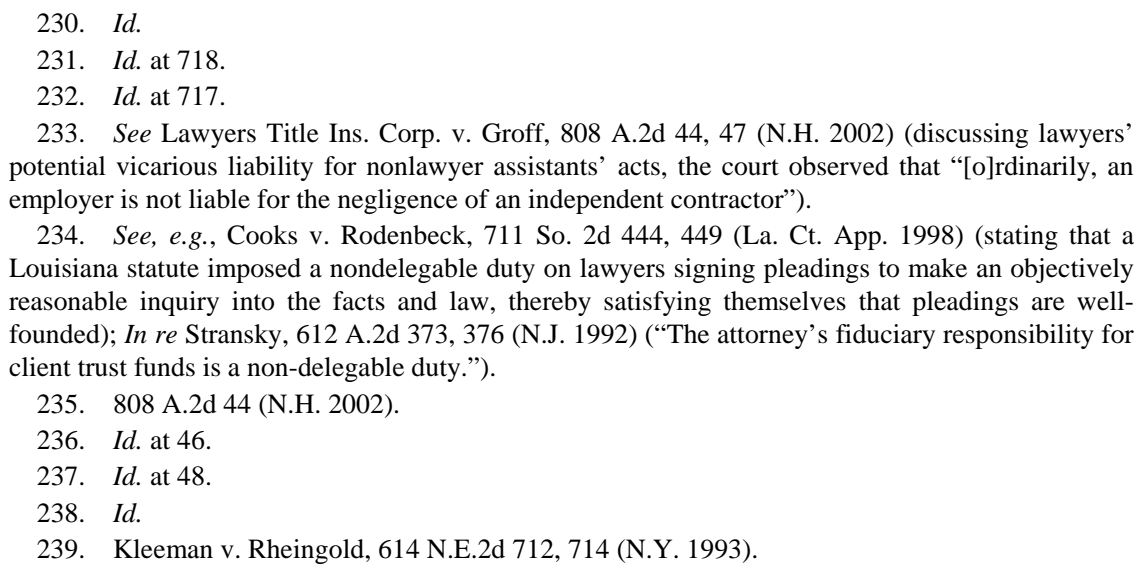


duty by retaining Fischer's, which held a state license. ${ }^{240}$ But the mere fact that Fischer's was licensed, while relevant, should not alone be sufficient to satisfy Rheingold's duty of care; the lower court should have required something more. ${ }^{241}$ Was Rheingold's law firm's regular use of Fischer's to serve process for the firm's clients, apparently without mishap, that "something more"? Perhaps it was, though it is difficult to answer this question without knowing more facts. ${ }^{242}$ It is fair to say that lawyers generally should attempt to perform reasonable due diligence on independent contractors before retaining them. The amount of diligence due will depend on the matter and may be affected by various factors, including the client, the lawyer's familiarity with the contractor, the task or project at issue, time constraints, geographic restraints or limitations, budgetary or expense concerns, and the availability of alternative service providers. Naturally, a lawyer's breach of duty does not end the analysis of negligent hiring or negligent supervision claims; a plaintiff additionally must establish proximate cause and damages to recover against the lawyer. ${ }^{243}$

\section{SPECIAL SUPERVISORY CHALLENGES OR RISKS}

Within the confines of Rule 5.3 and section 11 of the Restatement lie four special supervisory challenges or risks for lawyers: (a) the employment of family members as nonlawyer assistants, (b) the employment of disbarred lawyers as lay assistants, (c) the use of private investigators, and (d) outsourcing work to nonlawyers.

\section{A. Employing Family Members as Nonlawyer Assistants}

Lawyers regularly employ family members as lay assistants, although this practice is perhaps more pronounced in smaller law firms. Lawyers understandably believe their family members - especially close relatives - to be particularly trustworthy. Sadly, family members

\footnotetext{
240. Id.

241. See Feldman v. Upton, Cohen \& Slamowitz, 740 N.Y.S.2d 790, 793 (N.Y. Dist. Ct. 2002) (indicating that licensure would not be dispositive if a licensed process server had a "demonstrated record of persistent complaints and established unreliability”).

242. See id. (rejecting negligent hiring claim where lawyers testified that they had "no adverse experience" with the errant process server).

243. See RESTATEMENT (THIRD) OF AGENCY \& 7.05 cmt. c (2006) (stating that liability for negligent hiring, supervision, or training “is limited by basic principles of tort law," and specifically mentioning causation).
} 
employed as assistants sometimes betray lawyers' trust, subjecting lawyers to potential discipline for allegedly violating Rule 5.3. ${ }^{244}$

Consider, for example, a scheme perpetrated against a very good boutique litigation firm by the firm's office manager, who was the managing partner's sister-in-law. ${ }^{245}$ One of the firm's clients was a company with regular litigation needs. The firm charged the client a $\$ 10,000$ monthly advance payment retainer to encompass the first fifty hours of legal services provided each month. For monthly hours above fifty, the firm charged an hourly rate of $\$ 300$. The office manager collected the retainer the first day of every month by picking up a $\$ 10,000$ check from the client. Unfortunately, the office manager was a habitual gambler. To feed her addiction, she forged endorsements on the monthly retainer checks and stole the funds. To disguise the thefts, she inflated the client's monthly bills by thirty-four hours. The client was overbilled by nearly $\$ 300,000$ before the office manager's scheme was detected. When the client discovered the fraud and demanded repayment from the law firm, the firm sued its bank on various theories related to the forged endorsements on its retainer checks and the bank's alleged failure to detect and prevent the office manager's thefts. The law firm contended that the bank was solely responsible for the client's loss. The bank defended, in part, by alleging that the managing partner had violated his supervisory obligations under Rules 5.3(a) and (b), and that the firm thus bore the lion's share of the fault for the office manager's

244. See, e.g., In re Finestrauss, 32 A.3d 978, 979 (Del. 2011) (per curiam) (reprimanding lawyer for failing to supervise his bookkeeper-wife, who failed to pay various payroll tax obligations); In re Otlowski, No. 127, 2009, 2009 WL 1796083, at *3 (Del. June 23, 2009) (reprimanding lawyer whose daughter stole from his escrow account); In re Shamers, 873 A.2d 1089, 1094-98 (Del. 2005) (per curiam) (suspending lawyer for protracted failure to supervise his bookkeeper-wife); In re Galasso, 940 N.Y.S.2d 88, 91-93 (N.Y. App. Div. 2012) (per curiam) (suspending lawyer whose bookkeeper-brother misappropriated client funds), aff'd as modified, _N.E.2d_, 2012 WL 5199400 (N.Y. Oct. 23, 2012) (affirming violation of supervisory responsibilities but remanding for reconsideration of suspension as appropriate sanction after unrelated disciplinary charge was held to be unfounded); State ex rel. Okla. Bar Ass'n v. Hill, 281 P.3d 1264, 1268, 1272 (Okla. 2012) (finding that lawyer violated Oklahoma Rule 5.3 by failing to supervise his office manager-wife, who vindictively misappropriated funds from the lawyer's operating and trust accounts); In re McClain, 719 S.E.2d 675, 675-76 (S.C. 2011) (per curiam) (violating South Carolina Rule 5.3 by failing to supervise bookkeeper-wife, who was able to embezzle client funds from trust accounts as a result); In re Vanderbeek, 101 P.3d 88, 93-94 (Wash. 2004) (disciplining lawyer whose bookkeeper-husband "habitually added charges to clients' bills"; lawyer was not initially aware of husband's fraudulent scheme but "even minimal review of the bills or billing process should have revealed it to be happening" (internal quotation marks omitted)).

245. Confidentiality obligations prevent me from identifying the law firm. 
overbilling. $^{246}$ The firm settled with the bank for a fraction of its claim as a result.

Lawyers must satisfy their supervisory responsibilities even though they reasonably consider nonlawyer assistants to be capable and trustworthy. ${ }^{247}$ "Internal controls and supervisory review are essential precisely because employee dishonesty and incompetence are not always identifiable in advance.”248 Everyone makes mistakes. Valued employees may make misjudgments because of personal stresses or setbacks, depression, financial hardships, personality disorders, or substance abuse problems. For whatever reason, some people are simply dishonest. All of these things are as true for lawyers' relatives as they are for the population at large. A nonlawyer assistant's familial link to the lawyer does not diminish client harm caused by the assistant's misconduct. Accordingly, lawyers who hire family members as assistants cannot ignore their supervisory responsibilities for those people based on their relationships with them. ${ }^{249}$

\section{B. Employing or Retaining Disbarred Lawyers as Nonlawyer Assistants}

In addition to employing family members as nonlawyer assistants, lawyers also hire disbarred lawyers for paralegal and similar positions. On the one hand, lawyers' decisions to hire disbarred lawyers as assistants are understandable. These former lawyers have legal knowledge and training, substantive knowledge of various areas of the law, and a range of valuable practical experience and skills. ${ }^{250}$ They may have client relationships that are properly transferable to lawyers who employ them. If one believes in the power of remorse and the value of redemption, disbarment ought not force a person, who must earn a living

246. Lawyers are not excused from supervising nonlawyer assistants by virtue of the existence of others who are theoretically positioned to detect misconduct by the assistants. See, e.g., In re Paras, 742 N.E.2d 924, 925-26 (Ind. 2001) (per curiam) (disciplining lawyer in connection with secretary's trust account mismanagement even though some problems with the account were attributable to a bank's error).

247. In re Cater, 887 A.2d 1, 15 (D.C. 2005).

248. Id. at 15-16.

249. See Barbara Glesner Fines, Ethical Issues in Family Representations 69 (2010) (reminding lawyers to not allow personal relationships with nonlawyer assistants to interfere with supervision of those assistants).

250. See David Elkanich et al., Suspended Animation: A lawyer's Life as a Legal Assistant, OR. ST. B. BULL., Jan. 2006, at 27, 27 (observing that suspended lawyers employed as nonlawyer assistants "may bring with them a level of experience that can be of real value to the lawyers who employ them and their clients"). 
thereafter, to surrender all of her education and accumulated knowledge. On the other hand, courts reserve disbarment for only the gravest professional offenses, so banishment from the law is a reasonable consequence of such misconduct and is necessary to protect the public and the legal profession. In fact, disbarred lawyers working as lay assistants reoffend in their new roles with metronomic regularity-often with serious ramifications for the lawyers who hire them. ${ }^{251}$ Unauthorized practice of law by disbarred lawyers working as paralegals, or in similar capacities, is a serious threat, as such assistants may be unable to resist performing tasks they comfortably handled as practicing lawyers. ${ }^{252}$

A lawyer who is considering hiring a disbarred lawyer as a lay assistant should first search the law of the relevant jurisdiction, including case law, court rules, ethics opinions, rules of professional conduct, and statutes. Some jurisdictions prohibit lawyers or law firms from employing disbarred lawyers as assistants. ${ }^{253}$ For example, a Massachusetts Supreme Judicial Court Rule provides that no disbarred or suspended lawyer "shall engage in . . . paralegal work, and no lawyer or law firm shall knowingly employ or otherwise engage, directly or indirectly, in any capacity, a person who is suspended or disbarred by any court ....,"254 “Any capacity” as used in the rule means exactly what

251. See, e.g., In re Geary, 640 S.E.2d 253, 254 (Ga. 2007) (per curiam) (suspending a lawyer who relied on a disbarred lawyer to sign up a client and to deliver interrogatories to the client); In re Scott, 739 N.E.2d 658, 659-60 (Ind. 2000) (per curiam) (suspending a lawyer who, among other offenses, failed to supervise a disbarred lawyer who served as his paralegal and office manager; the disbarred lawyer engaged in the unauthorized practice of law); In re Juhnke, 41 P.3d 855, 859-61 (Kan. 2002) (per curiam) (censuring lawyer who allowed disbarred lawyer working as a paralegal to engage in the unauthorized practice of law); In re Comish, 889 So. 2d 236, 244-47 (La. 2004) (per curiam) (suspending a lawyer who employed a disbarred lawyer as a paralegal; the paralegal misappropriated funds and engaged in the unauthorized practice of law); Att'y Grievance Comm'n of Md. v. Brennan, 714 A.2d 157, 162-63 (Md. 1998) (suspending lawyer who employed a suspended lawyer as a paralegal; the suspended lawyer, while acting as a paralegal, engaged in the unauthorized practice of law).

252. In re Juhnke, 41 P.3d at 861; see also Pa. Eth. Op. 98-75, supra note 42, at *7 (noting that employing disbarred or suspended lawyers as legal assistants can be "problematic" for the employing lawyer because "from force of habit [the disbarred lawyer] may continue to act as a lawyer").

253. See, e.g., Miss. State Bar Ethics Comm., Formal Op. 96 (1984) ("It is not proper for an attorney to allow a disbarred or suspended attorney to work as a paralegal or legal assistant in the attorney’s law office.”); S.C. Bar Ethics Adv. Comm., Adv. Op. 92-20 (1992), 1992 WL 810436 (prohibiting lawyers from hiring disbarred lawyers "to do legal research and other paralegal work"); Wash. State Bar Ass'n Rules of Prof'l Conduct Comm., Adv. Op. 184 (1990) (interpreting Washington Rule 5.8(b) as prohibiting a lawyer "from hiring or employing a disbarred lawyer in connection with or related to the practice of law”).

254. MASs. SUP. JUD. CT. R. 4:01 § 17(7). 
it says: a lawyer or law firm cannot employ a suspended or disbarred lawyer "even ... a as a secretary, janitor, or messenger."255 A suspended or disbarred Massachusetts lawyer may, however, seek leave to be employed as a paralegal after four years in a case of indefinite suspension, or after seven years in a case of disbarment. ${ }^{256}$ Illinois Supreme Court Rule 764(b) provides that disbarred lawyers cannot "maintain a presence or occupy an office where the practice of law is conducted." 257 As written, the Rule suggests that an Illinois lawyer might permissibly engage a disbarred lawyer as a lay assistant, so long as the person worked away from the lawyer's office, but the Rule seems to be interpreted as flatly prohibiting the use of disbarred lawyers as nonlawyer assistants. ${ }^{258}$

The majority of jurisdictions, however, permit lawyers to employ disbarred lawyers as nonlawyer assistants under certain conditions. ${ }^{259}$ Some jurisdictions condition employment or retention of disbarred lawyers as nonlawyer assistants through court rules or provisions in their rules of professional conduct. ${ }^{260}$ For example, California Rule of Professional Conduct 1-311(B) provides that:

(B) A member shall not employ, associate professionally with, or aid a person the member knows or reasonably should know is a disbarred, suspended, resigned, or involuntarily inactive member to perform the following on behalf of the member's client:

(1) Render legal consultation or advice to the client;

(2) Appear on behalf of a client in any hearing or proceeding or before any judicial officer, arbitrator, mediator, court, public agency, referee, magistrate, commissioner, or hearing officer;

255. Nancy Kaufman, The Prohibition Against Employment of Suspended or Disbarred Lawyers, MASS.GOV (Nov. 1998), http://www.mass.gov/obcbbo/employ.htm.

256. MASS. SUP. JUD. CT. R. 4:01 § 18(3).

257. ILL. SUP. CT. R. 764(b).

258. See Hope Viner Samborn, Disbarred-But Not Barred From Work, ABA J., June 2007, at 57,57 (presenting this interpretation).

259. Ala. State Bar Disciplinary Comm’n, Formal Op. 1996-08 (1996) [hereinafter Ala. Op. No. 1996-08], available at http://www.alabar.org/ogc/fopDisplay.cfm?oneId=380.

260. See, e.g., Procedures of the ARK. Sup. Ct. Regulating Prof'L Conduct of ATTORNEYS AT LAW § 22 (2011), available at http://courts.arkansas.gov/professional_conduct/ documents/In_re_Procedures_of_the_Ark_Sup_Ct_Regulating_Prof_l_Conduct_of_Attorneys_at_L aw.pdf (limiting law practice-related activities in which disbarred Arkansas lawyers may engage); COLO. Rules OF PROF'L CONDUCT R. 5.5(c) \& (d) (2012) (establishing limits on work by disbarred or suspended lawyers); MinN. RULES OF PROF'L CONDUCT R. 5.8 (2011) (regulating lawyers' employment of disbarred, suspended, or involuntarily inactive lawyers as nonlawyer assistants). 
(3) Appear as a representative of the client at a deposition or other discovery matter;

(4) Negotiate or transact any matter for or on behalf of the client with third parties;

(5) Receive, disburse or otherwise handle the client's funds; or

(6) Engage in activities which constitute the practice of law. ${ }^{261}$

\section{Similarly, Georgia Rule of Professional Conduct 5.3(d) states that:}

d. a lawyer shall not allow any person who has been suspended or disbarred and who maintains a presence in an office where the practice of law is conducted by the lawyer, to:

1. represent himself or herself as a lawyer or person with similar status;

2. have any contact with the clients of the lawyer either in person, by telephone or in writing; or

3. have any contact with persons who have legal dealings with the office either in person, by telephone or in writing.

Other states have limited disbarred or suspended lawyers' activities as lay assistants through case law and ethics opinions. ${ }^{263}$ In In re Wilkinson, ${ }^{264}$ for example, the Kansas Supreme Court explained that a

261. Cal. Rules of Prof'L Conduct R. 1-311(B) (2008).

262. GA. Rules of PROF'L CONDUCT R. 5.3(d) (2012).

263. See, e.g., In re Frabizzio, 508 A.2d 468, 469 (Del. 1986) (explaining that a lawyer who was suspended from practice for two years could "perform the tasks usually performed by law clerks and by paralegals ... except that he [could] not have direct contact as a law clerk or paralegal with clients, witnesses, or prospective witnesses”); Att'y Grievance Comm'n of Md. v. Brennan, 714 A.2d 157, 162 (Md. 1998) (stating that a disbarred or suspended lawyer may work as a paralegal "provided that proper procedures and constraints are in place to assure that the public in general, and clients in particular, are not confused as to the person's status as a paralegal”); Ala. Op. No. 199608, supra note 259 (listing restrictions on disbarred or suspended lawyers working as lay assistants and imposing conditions on employing lawyer); Neb. Op. No. 11-01, supra note 36, at 7 (imposing numerous conditions on disbarred or suspended lawyers' activities when serving as nonlawyer assistants); N.C. State Bar, 98 Formal Op. 7 (1998), 1998 WL 609812, at *1-2 (permitting disbarred lawyers to work as paralegals except in the firm in which they practiced at the time of their disbarment); Ohio Bd. of Comm'rs on Grievances \& Discipline, Adv. Op. 90-06 (1990), 1990 WL 640501, at *2 [hereinafter Ohio Adv. Op. 90-06] (permitting disbarred lawyers to work as nonlawyer assistants and stating that employing lawyers must exercise "close supervisory control"); Or. State Bar Ass'n Bd. of Governors, Formal Op. 2005-24 (2005), 2005 WL 5679610, at *1 [hereinafter Or. Eth. Op. 2005-24] (prohibiting disbarred or suspended lawyers employed as nonlawyer assistants from sharing fees and practicing law).

264. 834 P.2d 1356 (Kan. 1992) (per curiam). 
disbarred or suspended lawyer may "work as a law clerk, investigator, paralegal, or in any capacity as a lay person for a licensed attorneyemployer" if the person's activities "are limited exclusively to work of a preparatory nature under the supervision of a licensed attorney-employer and [do] not involve client contact."265

Prudent lawyers will generally decline to employ or retain disbarred lawyers as lay assistants. Any advantages that disbarred lawyers may appear to offer prospective legal employers are outweighed by the risks that such assistants pose, ${ }^{266}$ and by the time and expense associated with effectively supervising their activities. ${ }^{267}$ At the very least, lawyers and law firms should be "especially circumspect" about entering into any sort of business relationship with a disbarred lawyer. ${ }^{268}$ If lawyers or law firms employ or retain disbarred lawyers as nonlawyer assistants, in the absence of jurisdictional authority they should (a) not engage in compensation practices that could reasonably be construed as sharing fees with the person; ${ }^{269}$ (b) not allow the person to appear in a representative capacity outside the presence of a lawyer, and, even in the presence of a lawyer, make clear that the person is appearing only as the lawyer's lay assistant; (c) not allow the person to have access to or control over client or law firm funds; ${ }^{270}$ (d) not permit the person to have any client contact outside the presence of a supervising lawyer; ${ }^{271}$ (e) not

\footnotetext{
265. Id. at 1362 .
}

266. See Ass'n of the Bar of the City of N.Y. Comm. on Prof'l \& Judicial Ethics, Formal Op. 1998-1 (1998), 1998 WL 1557150, at *3 [hereinafter N.Y.C. Eth. Op. 1998-1] (“[E]mployment of a disbarred lawyer is fraught with ethical peril even with respect to activities that nonlawyers may properly engage in. Courts may reasonably scrutinize [certain] activities and conclude that their performance by a disbarred lawyer poses greater risk to the public than their performance by a nonlawyer."); see also Okla. Bar Ass'n Legal Ethics Comm., Adv. Op. 319 (2002), 2002 WL 31990269, at *1 [hereinafter Okla. Adv. Op. 319] (quoting N.Y.C. Eth. Op. 1998-1 for the same proposition).

267. See Ala. Op. No. 1996-08, supra note 259 (stating that disbarred or suspended lawyers working as nonlawyer assistants must be closely supervised and such supervision "must be continuous and regular"); Neb. Op. No. 11-01, supra note 36, at 7 (explaining that disbarred or suspended lawyers serving as lay assistants are restricted from performing many activities and imposing tight restrictions on their work); Ohio Adv. Op. 90-06, supra note 263 , at *2 (requiring lawyers to "exercise close supervisory control" over disbarred lawyers functioning as nonlawyer assistants); Utah State Bar Ethics Adv. Op. Comm., Adv. Op. 99-02 (1999), 1999 WL 260749, at *2 (stating that lawyers who employ disbarred or suspended lawyers as paralegals "should take special care to ensure adequate supervision" of these assistants).

268. In re Discipio, 645 N.E.2d 906, 911 (Ill. 1994)

269. Or. Eth. Op. 2005-24, supra note 263, at*1.

270. See Ala. Op. No. 1996-08, supra note 259 (mentioning client funds).

271. Neb. Op. No. 11-01, supra note 36, at 7. 
permit the person to provide legal advice, guidance, or opinions; ${ }^{272}$ and (f) not permit the person to engage in any other activity that might be construed as the practice of law. ${ }^{273}$ This list is not exhaustive, and other restrictions or prohibitions may be appropriate in particular cases.

Lawyers must supervise disbarred lawyers working as nonlawyer assistants more closely than they would supervise other lay assistants because of these assistants' prior misconduct. ${ }^{274}$ This supervision must be "continuous and regular.",75 Supervising lawyers must review all assignments or tasks completed by disbarred lawyers working as nonlawyer assistants. ${ }^{276}$ For example, lawyers must review all correspondence and other documents prepared by disbarred lawyers functioning as nonlawyer assistants. ${ }^{277}$ If a lawyer employs or retains a disbarred lawyer to perform factual investigations in her capacity as a lay assistant, as disbarred lawyers are commonly permitted to do, ${ }^{278}$ the lawyer must carefully instruct her on the limits of her authority.

These are stringent requirements. In some instances, they may have the unfortunate effect of discouraging lawyers from employing or retaining disbarred lawyers as nonlawyer assistants, even though the would-be assistants deserve such opportunities. That is, however, an acceptable side effect of legitimate client-protection efforts.

\section{Lawyers' Use of Private Investigators}

Lawyers regularly retain private investigators in their practices. ${ }^{279}$ Lawyers may rely on private investigators to perform background checks on prospective employees of clients, investigate parties' or witnesses' histories, locate and interview potential witnesses, expose suspected employment or housing discrimination, discover and document copyright and trademark infringement, conduct due diligence in advance of

272. Id.; Okla. Adv. Op. 319, supra note 266, at *1.

273. N.Y.C. Eth. Op. 1998-1, supra note 266, at *7.

274. Neb. Op. No. 11-01, supra note 36, at 7.

275. Ala. Op. No. 1996-08, supra note 259.

276. Neb. Op. No. 11-01, supra note 36, at 7.

277. Id.

278. See, e.g., In re Wilkinson, 834 P.2d 1356, 1362 (Kan. 1992) (per curiam) (stating that disbarred lawyers may work as investigators and paralegals); Att'y Grievance Comm'n of Md. v. Brennan, 714 A.2d 157, 162 (Md. 1998) (observing that "[f]actual investigations, including the ascertainment of whether suitable medical, economic, or social resources exist that may be helpful to a client, may be undertaken by such persons").

279. Diane Saunders, Lessons from the Hewlett-Packard Spy Scandal, FoR THE DEF., Jan. 2007, at 76,76 . 
anticipated acquisitions or mergers, or investigate employee fraud or other workplace misconduct, to name only some common responsibilities. ${ }^{280}$ Unfortunately, lawyers sometimes "leave too much to chance as to whether investigators will stay within the bounds of the law and the ethics rules that constrain lawyer conduct.,281

Midwest Motor Sports v. Arctic Cat Sales, Inc. ${ }^{282}$ exemplifies the risks that accompany lawyers' use of private investigators. The case arose out of a dispute in a South Dakota federal court between a snowmobile manufacturer, Arctic Cat, and two of its dealers, Elliott and A-Tech. Elliott sued Arctic Cat for allegedly violating South Dakota franchise law by terminating Elliott's franchise and installing A-Tech as a new franchise in the same city. ${ }^{283}$ Arctic Cat's attorneys, Roger Damgaard and Timothy Shattuck, retained Adrian Mohr, a private investigator, to visit Elliott's showroom to determine what products Elliott was promoting, what brands of snowmobiles were selling best, and whether Elliott was suffering financially from the loss of the Arctic Cat franchise. ${ }^{284}$ Mohr wore a hidden recording device to capture his conversations with dealer personnel. ${ }^{285}$ Damgaard and Shattuck did not script questions for Mohr to ask during his showroom visits, but they did indicate subjects they wanted him to address. ${ }^{286}$ When Mohr asked whether he could legally record conversations with represented parties, "they assured him that his conduct was legal, [but did not] discuss with him the ethics rules governing his conduct as their agent."287

Mohr twice visited the Elliott showroom posing as a customer and recorded his conversations with an Elliott salesman. ${ }^{288}$ Mohr also visited the A-Tech showroom, where he recorded a conversation with A-Tech's president, Jon Becker. ${ }^{289}$ Again, Mohr knew of the lawsuit between Arctic Cat, Elliott, and A-Tech, and he further knew that Elliott and ATech were represented by counsel. ${ }^{290}$ He did not, however, reveal to

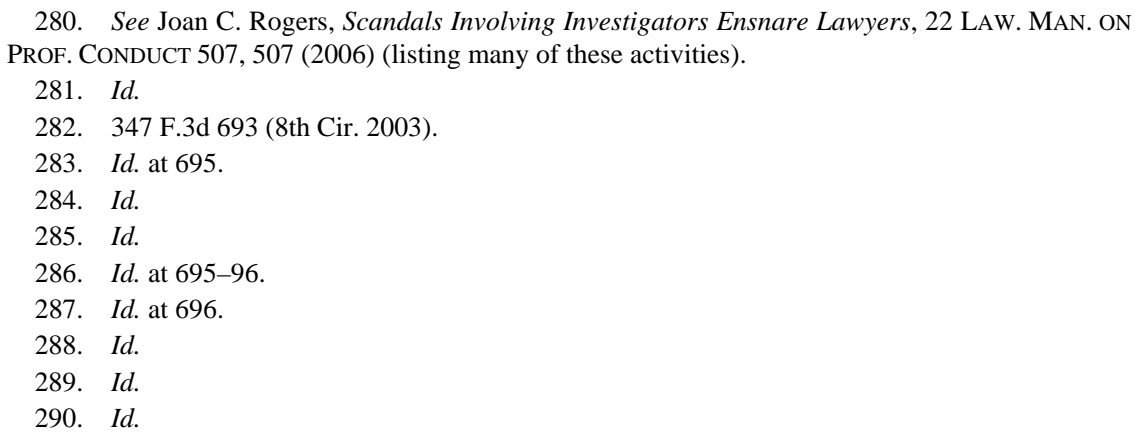


Elliott or A-Tech why he was visiting their dealerships, or that he was wearing a recording device. ${ }^{291}$ Mohr gave Damgaard and Shattuck copies of his recordings and snowmobile brochures that he picked up during his showroom visits. ${ }^{292}$ At the same time, Damgaard and Shattuck served Elliott and A-Tech with requests to inspect, photograph, and videotape their dealerships pursuant to Federal Rule of Civil Procedure $34 .{ }^{293}$

Elliott and A-Tech sought sanctions against Arctic Cat for Mohr's clandestine activities. ${ }^{294}$ As a sanction, the district court excluded Mohr's recordings and any evidence gleaned from them. ${ }^{295}$ Although the parties settled the franchise termination suit, they reserved the question of whether additional sanctions were appropriate. ${ }^{296}$ Both sides appealed sanctions issues to the Eighth Circuit.

One of the issues on appeal was Arctic Cat's counsel's alleged violation of South Dakota Rule 4.2 and, more specifically, whether Mohr spoke with anyone at Elliott or A-Tech who effectively personified either entity. ${ }^{297}$ Of course, Mohr had spoken with A-Tech's president, Becker. ${ }^{298}$ Damgaard and Shattuck tried to deflect responsibility for any violations to Mohr, saying that they directed him "to speak only to lowlevel salespeople for the purpose of becoming familiar with the Arctic Cat line.”299 The Eighth Circuit was unmoved by their argument:

[L]awyers cannot escape responsibility for the wrongdoing they supervise by asserting that it was their agents, not themselves, who committed the wrong. Although Arctic Cat's attorneys did not converse with Becker themselves, the Rules also prohibit contact performed by an investigator acting as counsel's agent.... "Since a lawyer is barred under Rule 4.2 from communicating with a represented party about the subject matter of the representation, she

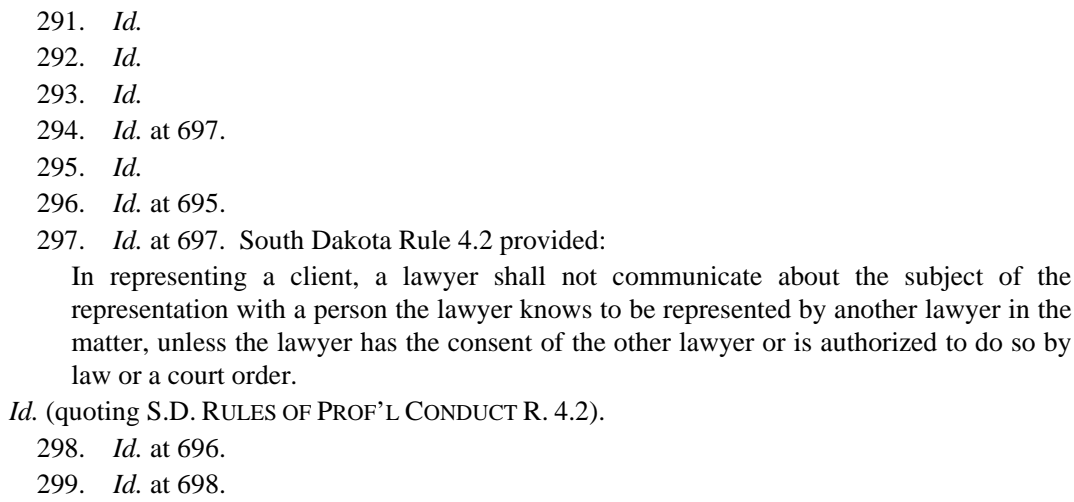
representation with a person the lawyer knows to be represented by another lawyer in the matter, unless the lawyer has the consent of the other lawyer or is authorized to do so by law or a court order.

Id. (quoting S.D. RULES OF PROF'L CONDUCT R. 4.2).

298. Id. at 696

299. Id. at 698 . 
may not circumvent the Rule by sending an investigator to do on her behalf that which she is herself forbidden to do.” ... In other words, an attorney is responsible for the misconduct of his nonlawyer employee or associate if the lawyer orders or ratifies the conduct.... Accordingly, we conclude that Arctic Cat's attorneys are ethically responsible for Mohr's conduct in communicating with Becker as if they had made the contact themselves. ${ }^{300}$

The court was also bothered by Mohr's conversations with Elliott's salesman, "Bill," who told him "that Elliott made a business decision to drop the Arctic Cat line"-a potentially damaging admission. ${ }^{301}$ Because Elliott's counsel clearly would have advised Bill against making such a statement to Mohr, the court had "no doubt" that South Dakota Rule 4.2 applied to Mohr's conversation with Bill. ${ }^{302}$

Although Damgaard's and Shattuck's South Dakota Rule 4.2 violations alone justified the imposition of sanctions, the Eighth Circuit reasoned that sanctions were further justified by the "false and misleading pretenses" under which Mohr visited Elliott and A-Tech. ${ }^{303}$ This was so even though South Dakota law permitted one party to a conversation to record that conversation without the other party's consent or knowledge. ${ }^{304}$ "[C]onduct that is legal may not be ethical," the court observed. ${ }^{305}$

The court reasoned that nonconsensual recordings should be prohibited where they are accompanied by other indicia of unethical behavior. $^{306}$ The South Dakota Rule 4.2 violations tipped the scales against Arctic Cat. Furthermore, the "duty to refrain from conduct that involves deceit or misrepresentation should preclude any attorney from participating in the type of surreptitious conduct that occurred here.”307 Arctic Cat employed Mohr in a ruse to gain an advantage at trial, triggering the South Dakota Rule 8.4(c) prohibition on "conduct involving dishonesty, fraud, deceit or misrepresentation.”308 The court also rejected Arctic Cat's defense that it employed Mohr only after

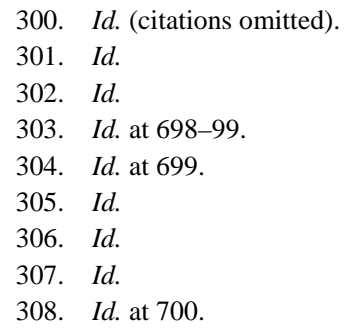


traditional discovery efforts failed. ${ }^{309}$ If Arctic Cat was frustrated by Elliott's or A-Tech's failure to cooperate in discovery, its remedy was a motion to compel discovery, not self-help. ${ }^{310}$

Ultimately, the Eighth Circuit affirmed the district court's order excluding Mohr's tapes and any derivative evidence. ${ }^{311}$ The Midwest Motor Sports court declined to impose monetary sanctions against Arctic Cat or its lawyers. ${ }^{312}$

Midwest Motor Sports is not the only case of its type. In In re Ositis, ${ }^{313}$ for example, the Oregon Supreme Court publicly reprimanded a lawyer who instructed a private investigator to pose as a journalist to interview a party to a potential dispute. ${ }^{314}$ Nor is courts' willingness to hold lawyers accountable for investigators' conduct a recent phenomenon. Indeed, the risks attending lawyers' involvement in investigations were highlighted nearly forty years ago in Noble v. Sears, Roebuck \& Co. ${ }^{315}$ In Noble, a private investigator hired by defense lawyers in a personal injury action slipped into the plaintiff's hospital room and deceptively obtained the address of a key witness. ${ }^{316}$ The plaintiff sued the investigator and defense lawyers. ${ }^{317}$ The Noble court held that an unreasonably intrusive investigation such as this one may violate a plaintiff's right to privacy. ${ }^{318}$ The court further found that the plaintiff could sue the defense lawyers for the investigator's tortious conduct on vicarious liability principles, and that the lawyers might be directly liable for negligently hiring and supervising the investigator. ${ }^{319}$

Lawyers who retain private investigators should exercise reasonable care in hiring. ${ }^{320}$ The determination of whether a lawyer exercised reasonable care will depend on the facts of the case, but there are some general guidelines that lawyers may wish to follow. First, lawyers

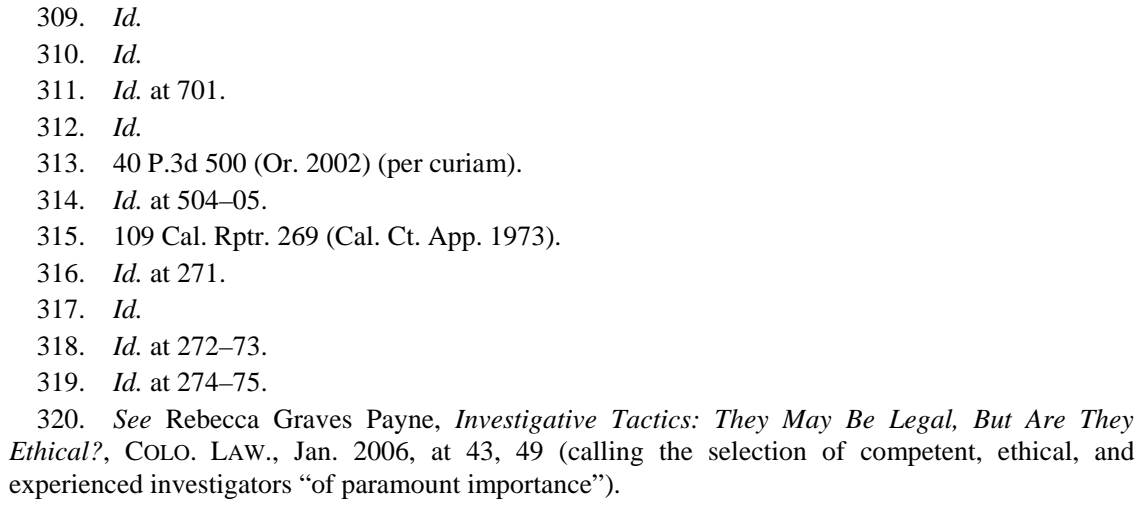


should ensure that investigators are properly licensed and hold any necessary business or professional permits. ${ }^{321}$ The lack of required licenses or permits is an automatic disqualifier. Second, unless lawyers have prior satisfactory experience with an investigator, they should ask the investigator for references from other lawyers and check them before retaining the investigator. ${ }^{322}$ Third, lawyers should interview prospective investigators regarding their experience. ${ }^{323}$ Public law enforcement experience is generally a favorable qualification for an investigator because of the training law enforcement officers receive, ${ }^{324}$ although it obviously does not guarantee responsible conduct by the investigator. ${ }^{325}$ Fourth, when hiring an investigative agency or company, lawyers should require the organization to identify the investigators who will be assigned to the matter. ${ }^{326}$ Lawyers should check those investigators' qualifications. $^{327}$ Fifth, lawyers should determine whether an investigator is a member of professional organizations with ethics codes or rules, or has earned certifications or designations reflecting special expertise or professional achievement. ${ }^{328}$ The lack of such credentials is not necessarily a basis to eliminate an investigator from consideration, but it may influence the selection of one investigator over another. Sixth, lawyers should research prospective investigators online to see what others are saying or writing about them and, equally important, what they have posted online. ${ }^{329}$ Finally, where feasible, lawyers should "check with the appropriate licensing body to determine whether the investigator has been the subject of complaints or has been professionally disciplined." 330

Once a lawyer selects a private investigator, the lawyer must instruct the investigator on the ethical and legal limits of the investigator's conduct. $^{331}$ The lawyer should document those instructions. ${ }^{332}$

321. Richmond ET AL., supra note 28, at 199; Robert L. Reibold, Hidden Dangers of Using Private Investigators, S.C. LAW., July 2005, at 18, 29.

322. RICHMOND ET AL., supra note 28, at 199; Reibold, supra note 321, at 29.

323. RICHMOND ET AL., supra note 28, at 199; Reibold, supra note 321, at 29.

324. RICHMOND ET AL., supra note 28, at 199.

325. Payne, supra note 320, at 49-50.

326. RichMOND ET AL., supra note 28, at 199; Reibold, supra note 321, at 29.

327. RICHMOND ET AL., supra note 28, at 199.

328. Id.

329. Id

330. Id. One commentator has described this step as "go[ing] the extra mile" where it requires a lawyer to make a Freedom of Information Act Request to obtain the information. Reibold, supra note 321 , at 29.

331. RichMOND ET AL., supra note 28, at 199. 
Thereafter, the lawyer must pay attention to what the investigator is doing and provide reasonable guidance. Admittedly, there is tension here. If the lawyer has the right to control the details of the investigator's work, the lawyer risks vicarious liability for any alleged misconduct by the investigator. ${ }^{333}$ At the same time, the investigator's status as an independent contractor will not shield the lawyer against professional discipline for violating Rule 5.3(b) through inadequate supervision of the investigator's activities. In addition, there is at least some authority for the position that those who retain investigators sometimes owe a nondelegable duty to conduct the investigation lawfully, thus defeating any independent contractor defense. ${ }^{334}$

In conclusion, lawyers are generally better advised to closely supervise private investigators' activities than to attempt to distance themselves from them. The former approach reduces the likelihood of alleged misconduct by investigators, while the latter tack affords no defense to professional discipline and may be of limited utility if a lawyer is forced to defend allegations of civil or criminal liability.

\section{Outsourcing}

"Outsourcing" describes the practice of sending work traditionally handled inside a law firm to an outside contractor for performance. ${ }^{335}$ Law firms now outsource many of their back office functions, such as accounting, word processing, information management and technology, and human resources. ${ }^{336}$ In some instances, these functions are performed by nonlawyers working overseas or in domestic locations far from the firm's offices, where wages are lower and benefits, if any, cost less. $^{337}$ Firms also outsource work for clients to nonlawyers. For

332. Id.

333. Singletary v. Fridley, 762 So. 2d 692, 693-94 (La. Ct. App. 2000).

334. See, e.g., Ellenberg v. Pinkerton’s, Inc., 188 S.E.2d 911, 914 (Ga. Ct. App. 1972) (recognizing nondelegable duty rendering independent contractor defense inapplicable where investigator allegedly violated plaintiff's right to privacy); King v. Loessin, 572 S.W.2d 87, 90 (Tex. App. 1978) (involving the retention of a private investigator to "perform a service unlawful in itself").

335. Brandon Robers, The Firm Is Flat: Ethical Implications of Legal Offshoring, 23 GEO. J. Legal Ethics 799, 800 (2010) (quoting Marcia L. Proctor, Considerations in Outsourcing Legal Work, MicH. B.J., Sept. 2005, at 20, 20).

336. Mary C. Daly \& Carole Silver, Flattening the World of Legal Services? The Ethical \& Liability Minefields of Offshoring Legal \& Law-Related Services, 38 GEO. J. INT’L L. 401, 404 (2007); Kathryn A. Thompson, Still the Boss, ABA J., June 2006, at 26, 26.

337. Elizabeth Dilts, Eastward Ho!, AM. LAW., Sept. 2012, at 26, 26; Amy Jo Ehman, What's Happening in Back Office Outsourcing, PRACTICE LINK (2012), http://www.cba.org/cba/Practice 
example, law firms may outsource various aspects of discovery and document review to outside paralegals. ${ }^{338}$ The advantage, again, is perceived cost savings. ${ }^{339}$ Perhaps the best and most basic example of lawyers outsourcing work for clients-and certainly the least controversial-is lawyers' use of outside vendors to handle large photocopying projects, rather than having law firm staff make the copies.

Bar ethics committees that have analyzed outsourcing have uniformly opined that the practice is generally permissible. ${ }^{340}$ Lawyers' ability to fulfill their supervisory duties, however, has understandably been an area of focus.

For example, in 2006 the New York City Bar Association-then known as the Association of the Bar of the City of New York-was asked whether a lawyer could ethically outsource legal support services overseas to lawyers not admitted to practice in New York or any other United States' jurisdictions, or to laypersons and, relatedly, what issues the lawyer should consider in the process. ${ }^{341}$ The New York City Bar was initially concerned about the lawyer's possible assistance of the foreign lawyers or laypersons in the unauthorized practice of law. ${ }^{342}$ To avoid aiding the unauthorized practice of law, the New York City Bar explained, "the lawyer must at every step shoulder complete responsibility for the non-lawyer's work. In short, the lawyer must... set the appropriate scope for the non-lawyer's work and then vet the nonlawyer's work and ensure its quality." ${ }^{\text {"33 }}$ After reciting lawyers' supervisory obligations for other lawyers and nonlawyer assistants and noting the hurdles posed by the lawyer's physical separation from the

Link/wwp/PrintHTML.aspx?DocId=31570.

338. Robers, supra note 335, at 802.

339. See Douglas R. Richmond, Outsourcing Legal Work... Do Professional Liability \& Responsibility Go Along?, Of COUNSEL, Feb. 2005, at 5, 5 (stating by way of example that paralegals in the United States earn an average of $\$ 18$ per hour, while paralegals in India earn between $\$ 6$ and $\$ 8$ per hour).

340. ABA Comm. on Ethics \& Prof'l Responsibility, Formal Op. 08-451 (2008); Fla. State Bar Ass'n Comm. on Prof'l Ethics, Adv. Op. 07-2 (2008), 2008 WL 3556663; L.A. Cnty. Bar Ass'n Prof'l Responsibility \& Ethics Comm., Op. 518 (2006), http://www.lacba.org/Files/LAL/ Vol29No9/2317.pdf; N.H. Bar Ass'n, Ethics Comm., Adv. Op. 2011-12/5 (2011); The Ass'n of the Bar of the City of New York Comm. on Prof'l \& Judicial Ethics, Adv. Op. 2006-3 (2006), 2006 WL 2389364 [hereinafter N.Y.C. Eth. Op. 2006-3]; N.C. State Bar, Formal Op. 12 (2008), 2008 WL 5021151 [hereinafter 2007 N.C. Eth. Op. 12]; San Diego Cnty. Bar Ass’n Legal Ethics Comm., Op. 2007-1 (2007), available at http://www.sdcba.org/index.cfm?Pg=ethicsopinion07-1.

341. N.Y.C. Eth. Op. 2006-3, supra note 340, at *1.

342. Id. at *2-3.

343. Id. at $* 3$. 
prospective service provider, ${ }^{344}$ the New York City Bar asserted that the lawyer had to be "both vigilant and creative in discharging the duty to supervise." ${ }^{345}$

In attempting to formulate supervisory guidelines for the lawyer to follow, the New York City Bar prudently noted that each outsourcing situation is different. ${ }^{346}$ The Bar did, however, recommend the following "salutary steps":

(a) obtain background information about any intermediary employing or engaging the non-lawyer, and obtain the professional résumé of the non-lawyer; (b) conduct reference checks; (c) interview the non-lawyer in advance, for example, by telephone or by voice-over-internet protocol or by web cast, to ascertain the particular non-lawyer's suitability for the particular assignment; and (d) communicate with the non-lawyer during the assignment to ensure that the non-lawyer understands the assignment and that the non-lawyer is discharging the assignment according to the lawyer's expectations.

In 2008, the ABA's Standing Committee on Ethics \& Professional Responsibility issued Formal Opinion 08-451 discussing lawyers' obligations when outsourcing legal and nonlegal support services. ${ }^{348}$ The Committee specifically noted that Model Rule 5.3(b) applies to outsourced work performed by nonlawyers. ${ }^{349}$ Like the New York City Bar, the Committee recognized the supervisory challenges posed by outsourcing work to providers who are physically separated from the assigning lawyers and may be working in different time zones. ${ }^{350}$ The Committee acknowledged that electronic communications may close some associated gaps, but recognized that they may not always be adequate. $^{351}$ As for supervisory guidelines, the Committee stated:

At a minimum, a lawyer outsourcing services for ultimate provision to a client should consider conducting reference checks and investigating the background of the ... nonlawyer providing the services as well as any nonlawyer intermediary involved, such as a placement agency or service provider.... When dealing with an intermediary, the lawyer

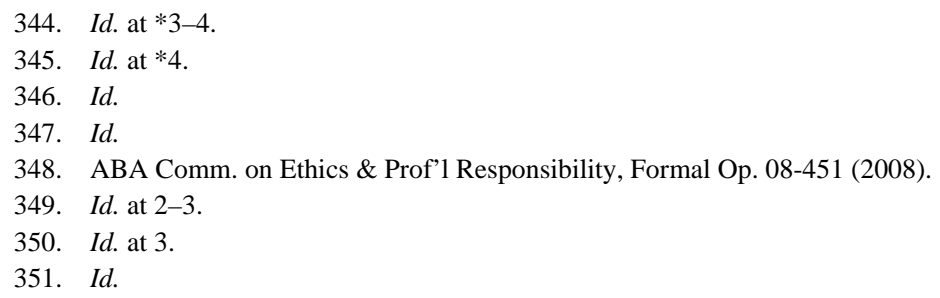


may wish to inquire into its hiring practices to evaluate the quality and character of the employees likely to have access to client information. Depending on the sensitivity of the information being provided to the service provider, the lawyer should consider investigating the security of the provider's premises, computer network, and perhaps even its recycling and refuse disposal procedures. In some instances, it may be prudent to pay a personal visit to the intermediary's facility, regardless of its location or the difficulty of travel, to get a firsthand sense of its operation and the professionalism of the... nonlawyers it is procuring. $^{352}$

Outsourcing arrangements vary, and the measures required for lawyers to satisfy their supervisory obligations will accordingly differ by matter. ${ }^{353}$ As the ABA's Ethics 20/20 Commission has recognized in proposing outsourcing-related amendments to the comments to Rule 5.3, the extent of a lawyer's supervisory obligation will depend

upon the circumstances, including the education, experience and reputation of the nonlawyer; the nature of the services involved; the terms of any arrangements concerning the protection of client information; and the legal and ethical environments of the jurisdictions in which the services will be performed, particularly with regard to confidentiality.

As a general rule, however, lawyers should consider taking the following steps to satisfy their duties under Rule 5.3. First, lawyers ought to reasonably investigate the provider's background and capabilities before engaging the company or person. ${ }^{355}$ Lawyers should request and check references for the provider. Lawyers should satisfy themselves that a provider is competent to perform the intended assignment. Second, lawyers should instruct the provider on confidentiality and conflict of interest issues before retaining the provider. $^{356}$ Third, lawyers should carefully instruct the provider on the work to be performed and ensure that the provider understands the instructions. ${ }^{357}$ Fourth, lawyers ought to communicate with the provider during assignments to confirm that the provider's performance meets

352. Id

353. See N.Y.C. Eth. Op. 2006-3, supra note 340, at *1 (noting that each outsourcing situation is different).

354. Am. Bar Ass'n, ABA Comm'n on Ethics 20/20 Revised Proposal-Outsourcing, at 4 (2011).

355. N.Y.C. Eth. Op. 2006-3, supra note 340, at *4.

356. See id. (citations omitted).

357. 2007 N.C. Eth. Op. 12, supra note 340, at *2. 
requirements. $^{358}$ Finally, a lawyer should check the provider's work upon completion of the assignment to establish that it was performed appropriately. ${ }^{359}$

The fourth and fifth steps listed above in some cases can be complicated by clients' expectations. That is, a client may require a lawyer to outsource work to save money and, correspondingly, expect that the lawyer will not erase those savings by duplicating in any fashion the outsourced work. Thus, a client may instruct a lawyer not to involve herself in the work being outsourced, or refuse to pay for her services if she does. Presently, Rule 5.3 does not anticipate or address this collision between a client's interests and a lawyer's supervisory obligations. But, because Rule 5.3 exists to protect clients' interests, ${ }^{360}$ lawyers should be able to ethically honor clients' demands for reduced supervision of nonlawyers. As for practical guidance, lawyers facing this scenario should counsel the client about the potential risks of limiting the lawyer's supervision of the outsourced work, document that consultation and the client's instructions, inform the client of any developments that might cause the client to alter its instructions, and create a record of the lawyer's and the service provider's related responsibilities.

\section{CONCLUSION}

Lawyers depend on the efforts and support of many different nonlawyer assistants in their practices. Law firms could not operate without nonlawyer staff. Lawyers reach outside their firms for assistance from appraisers, private investigators, process servers, e-discovery vendors, and others. Law firms outsource various projects to a range of service providers. The list of nonlawyers who regularly assist lawyers in their practices is long.

Unfortunately, lawyers' lay assistants sometimes err and occasionally commit intentional misconduct. Lawyers called to account for problems caused by nonlawyer assistants' misconduct generally cannot deflect responsibility to the assistants. Model Rule of

358. N.Y.C. Eth. Op. 2006-3, supra note 340, at *4; 2007 N.C. Eth. Op. 12, supra note 340, at $* 2$.

359. 2007 NC Eth. Op. 12, supra note 340, at *2.

360. See RotUNDA \& DZIENKOWSKI, supra note 7, § 5.3-1, at 1006 ("Clients hire lawyers and law firms to represent their interests and although they may understand that parts of the work may be performed by nonlawyers, clients expect lawyers to adequately supervise the delivery of legal services by the firm.”). 
Professional Conduct 5.3 and equivalent state rules frequently prohibit lawyers from disavowing responsibility for assistants' conduct by imposing broad supervisory responsibilities on lawyers. Lawyers must understand their supervisory obligations and work diligently to fulfill them. The many cases in which courts have found Rule 5.3 violations highlight the importance of lawyers' supervisory responsibilities for lay assistants and, equally, demonstrate how easy it is for lawyers to fail in their duties. There may be many reasons for these lapses, but there are no satisfactory excuses. 